\title{
Quality of seeds of jatobá-do-cerrado processed and stored in diferents forms
}

\section{Qualidade de sementes de jatobá-do-cerrado processadas e armazenadas em diferentes formas}

\author{
Paulo Carteri Coradi ${ }^{*}$; Taísa Lopes Lacerda Pereira²; Lucas Jandrey Camilo ${ }^{3}$
}

\begin{abstract}
The preservation of the physical and chemical quality of jatobá-do-cerrado seeds during processing and storage is essential to the restocking of vegetation in degraded areas. Since no scientific studies have analysed the optimal post-harvest conditions for jatobá-do-cerrado seeds, this study aimed to evaluate the physical and chemical quality of jatobá-do-cerrado seeds following different types of processing: with pulp, without pulp (scarification), without pulp (fermentation) and at different storage temperatures $\left(10\right.$ and $23^{\circ} \mathrm{C}$ ) and different packaging (tetrapack, paper, plastic, PET bottles and glass bottles), over six months. The physical and chemical constituents of jatobá-do-cerrado seeds varied according to the packaging conditions. An increased storage time reduced the quality of the seeds. Seeds with pulp showed better physical characteristics during storage. The pulping processing of seeds by mechanical scarification increased the acidity and ash content, but led to the highest percentage of crude protein during storage at $23{ }^{\circ} \mathrm{C}$. The fermentation method of seed pulping positively affected seed quality during storage at $10{ }^{\circ} \mathrm{C}$. Permeable packaging (paper bags and tetrapack) led to a greater reduction in seed quality than that in glass bottles, PET bottles or plastic bags. The best conditions for the processing of jatobá-do-cerrado seeds was fermentation and the best storage condition was in waterproof packaging (glass or PET bottles).
\end{abstract}

Key words: Post-harvest. Packaging. Temperature.

\section{Resumo}

A preservação da qualidade física e química no processamento de sementes de jatobá-do-cerrado e armazenamento são fundamentais para o repovoamento de vegetação em áreas degradadas. Como não existem estudos científicos que comprovem as melhores condições na pós-colheita de sementes de jatobá-do-cerrado, este estudo teve como objetivo avaliar a qualidade físico-química das sementes jatobá-do-cerrado, em diferentes formas de processamento com polpa, sem polpa (escarificação), sem polpa (fermentado) e condições de temperatura de armazenamento $\left(10\right.$ e $\left.23^{\circ} \mathrm{C}\right)$ e embalagens (tetrapack, papel, plástico, garrafas PET e embalagens de vidro), ao longo de seis meses. Os constituintes físicos e químicos das sementes de jatobá-do-cerrado variaram de acordo com as condições avaliadas e embalagem. O aumento do tempo de armazenamento reduziu a qualidade das sementes. As sementes com polpa mantiveram melhor as características físicas ao longo do tempo de armazenamento. O processo de despolpamento das sementes pela escarificação aumentou o índice de acidez e cinzas, porém apresentou as maiores porcentagens de proteína bruta nas condições de acondicionamento com temperatura de

\footnotetext{
${ }^{1}$ Prof. Dr., Campus de Chapadão do Sul, Universidade Federal de Mato Grosso do Sul, UFMS, Chapadão do Sul, MS, Brasil. E-mail: paulocoradi@yahoo.com.br

${ }^{2}$ Discente do Curso de Eng ${ }^{\text {a }}$ Florestal, Campus de Chapadão do Sul, UFMS, Chapadão do Sul, MS, Brasil. E-mail: taisallacerda@ gmail.com

${ }^{3}$ Discente do Curso de Graduação em Agronomia, Campus de Chapadão do Sul, UFMS, Chapadão do Sul, MS, Brasil. Bolsista CNPq de Iniciação Científica. E-mail: luucasjandrey@hotmal.com

* Author for correspondence
} 
$23{ }^{\circ} \mathrm{C}$. O método de despolpamento das sementes pela fermentação foi favorável a qualidade para as condições de armazenamento na temperatura de $10{ }^{\circ} \mathrm{C}$. As embalagens permeáveis (sacos de papel e tetrapack) interferiram mais na redução da qualidade das sementes que as embalagens de frasco de vidro, sacos plásticos e garrafas PET. As melhores condições de processamento das sementes de jatobá-do-cerrado foi o método de fermentação e as melhores condições de armazenamento foram com embalagens impermeáveis (frascos de vidro e garrafas PET).

Palavras-chave: Pós-colheita. Acondicionamento. Temperatura.

\section{Introduction}

Jatobá-do-cerrado (Hymeneae courbaril Linn.) Fabaceae-Caesalpinioideae is a tree that originates from the Brazilian Amazon and Atlantic Forest, where it occurs naturally from Piauí to the north of Paraná. Jatobá-do-cerrado wood is used in the construction and the furniture industry, the fruits are used in the food industry and the leaves and seeds in the pharmaceutical and cosmetic industry. The plant pods are palatable and have a high nutritional value and are low in anti-nutritional compounds (BRAVO et al., 1994). Jatobá-do-cerrado is a characteristic legume of the Brazilian cerrado; the plant is 4-6 m in height and produces fruit that is between 6 and $18 \mathrm{~cm}$ long and 3-6 $\mathrm{cm}$ in diameter. Its starchy fruits are edible and are highly valued by the regional population and can be consumed or used as an ingredient in the preparation of cakes, breads and porridges, biscuits and snacks with a high fibre content (SILVA et al., 2001).

Jatobá-do-cerrado seeds can also be used as a source of galactomannans and xyloglucans by the food and pharmaceutical industries. The rheological properties of xyloglucans and galactomannans determine their use as emulsifiers, dispersants, and thickeners (MATUDA; MARIA NETO, 2005; OLIVEIRA et al., 2011).

Depending on the use and importance of jatobádo-cerrado seeds, post-harvest techniques can be used to increase production and to improve seed quality. Thus, it is important to collect seeds at the time of dispersion, to store them and to plant them when the soil is sufficiently moist in the rainy season. This practice can increase seed germination and lead to the establishment of uniform seedlings
(FONSECA et al., 2005; OLIVEIRA et al., 2011; CARVALHO; NAKAGAWA, 2012). This method is particularly important for the restoration of open areas, where the desiccation of seeds and seedlings is more critical. Another advantage of delayed dispersal is to reduce the time in which the seeds are available for predators, which is another major obstacle for the germination of seeds and consequently, for forest regeneration (OLIVEIRA et al., 2011).

The storage step contributes significantly to obtaining seeds during conventional periods for sowing, and to achieve standards of quality and homogeneity. For this, it is necessary to provide the optimal storage conditions, type of packaging and maximum storage time for each species. Some species can be dehydrated and subsequently stored at low temperatures, to achieve longevity. For conventional systems of genebanks, the stockpiles of seeds are stored under controlled conditions at a temperature of $10^{\circ} \mathrm{C}$ and $40 \%$ relative humidity. Even though the seeds in these databases are kept for a reasonable time, this does not prevent the erosion of genetic species, considering that the metabolism of seeds is completely blocked only at temperatures below $-130^{\circ} \mathrm{C}$ (CARVALHO, 2005; OLIVEIRA et al., 2012).

The determination of the physical properties of jatobá-do-cerrado seeds becomes important because it aims to develop processing equipment (ANDRADE et al., 2010; SOUSA et al., 2012). According to Gomes Junior (2010), knowledge concerning the shape and size of the seeds is essential to design processing machinery or to analyse seed quality during the stages of pre-processing and storage. Seed biometrics also represents an 
important tool with which to distinguish species of the same genus and varieties of the same species. Seed biometrics relate to the dispersion characteristics and seedling establishment, and are used to distinguish pioneer and non-pioneer species in tropical forests. Antagonism exists between seed size and the number of seeds per fruit for most shrub and tree species (ALVES et al., 2007).

Since no scientific studies have described the optimal conditions for the processing and storage of jatobá-do-cerrado seeds, the aim of this study was to evaluate the physical-chemical qualities of jatobádo-cerrado seeds processed by different methods and stored in different conditions of temperature and packaging, over a six-month period.

\section{Material and Methods}

The research was conducted at the Federal University of Mato Grosso do Sul (UFMS), the Campus of Chapadão do Sul (CPCS), in the Grain Postharvest Laboratory. Jatobá-do-cerrado seeds were harvested from farms located in the municipally of Chapadão do Sul/MS by hand and were dried at ambient air temperature. A portion of the seeds was processed to remove the pulp. Two different processing methods were used: manual scarification and fermentation. In manual scarification, a cutting blade was used to manually remove the pulp, whereas in processing via fermentation, the dry seeds were submerged in water for $24 \mathrm{~h}$, before being removed from the pulp manually. Seeds with and without pulp were stored at either 10 or $23{ }^{\circ} \mathrm{C}$, in plastic bags, paper bags, tetrapak boxes, PETtype containers or glass.

The quality analysis was performed at time zero, and after three and six months and consisted of the following measurements: physical properties, water content, crude protein, ash and acidity value. The water content was determined by the standard oven method at $105^{\circ} \mathrm{C} \pm 5{ }^{\circ} \mathrm{C}$ for $24 \mathrm{~h}$ with three replications as recommended (AOAC, 2000). The size of the seeds was determined by measuring the length, width and thickness of each seed with a caliper to $0.01 \mathrm{~mm}$ resolution after drying at different temperatures.

The bulk density of jabotá seeds was determined by the supplementary volume method, using volumetric flasks $(10 \pm 0.04 \mathrm{~mL})$ and an analytical balance (to $0.0001 \mathrm{~g}$ precision). Soybean oil was used as an additional volume of liquid. For the determination, five samples were used for each storage temperature, each containing thirty seeds. The density of the liquid (soybean oil) was obtained by the ratio between the mass and volume of the fluid from the balloon. The empty volumetric flask was weighed initially and was reweighed with oil to the $10 \mathrm{~mL}$ mark. The bulk density of the jabotá seeds was determined by placing each sample within a container of known volume and mass. The volume within the flask was then supplemented with soybean oil to a volume of $35.10 \mathrm{~mL}$ and the flask was reweighed. Knowing the mass of the liquid used in the supplementary volume (obtained by subtraction), and its density allowed the volume occupied by the seeds to be calculated. The bulk density of the seeds was determined by the relationship between seed mass and volume, equation (1).

$$
\rho_{a p}=m / V
$$

which,

$\rho_{\text {ap }}$ : bulk density of the product, $\left(\mathrm{kg} \mathrm{m}^{-3}\right)$

$\mathrm{m}$ : product mass, $(\mathrm{kg})$

$\mathrm{V}$ : volume, $\left(\mathrm{mm}^{3}\right)$

To calculate the projected area of the estimated seed, equation was used (2).

$$
A_{p}=3.14 A B
$$

which,

$A_{\mathrm{p}}$ : projected area, $\left(\mathrm{mm}^{2}\right)$

A: semi-major axis, (mm)

B: minor semi-axis, (mm) 
The sphericity (MOHSENIN, 1986), was calculated based on the geometric mean of three measurements perpendicular to the body axis relative to the major axis, according to equation (3).

$$
S={\frac{(\pi a b c)^{1 / 3}}{a}}^{1 / 3}
$$

which,

S: sphericity, the dimensionless

a: major axis, $(\mathrm{mm})$

b: average axis, (mm)

c: minor axis, $(\mathrm{mm})$

The circularity was determined according to equation (4) (MOHSENIN, 1986).

$$
C=A_{p} / A_{c}
$$

which,

$\mathrm{C}$ : is the circularity, dimensionless;

$A_{p}:$ is the diameter of the largest circle inscribed in the projection of the object at rest, $\left(\mathrm{mm}^{2}\right)$

$A_{c}:$ is the diameter of the smallest circumscribed circle in the projection of the object at rest, $\left(\mathrm{mm}^{2}\right)$

The form was determined by taking into account the seed sphericity and roundness (MOHSENIN, 1986). The porosity was determined by the direct method (MOHSENIN, 1986), by adding a known mass to the spaces of the granular liquid volume. A $30 \mathrm{~mL}$ beaker and a $50 \mathrm{~mL}$ burette were used, together with soybean oil. The porosity was calculated by equation 6 .

$$
\varepsilon=\left[1-\left(\frac{\rho_{a p}}{\rho_{u n}}\right)\right]
$$

which,

$\varepsilon$ : porosity, (\%) $r_{\text {ap }}$ : bulk density apparent, $\left(\mathrm{kg} \mathrm{m}^{-3}\right)$

$r_{u m}$ : specific mass unit, $\left(\mathrm{kg} \mathrm{m}^{-3}\right)$

The specific mass was estimated or measured, depending on the porosity and the bulk density of the seed mass according to the following relationship, equation (7) (MOHSENIN, 1986).

$$
\rho_{\mu}=\rho_{a p} /(\varepsilon-1)
$$

which,

$\rho_{\mu}$ : specific mass unit, $\left(\mathrm{kg} \mathrm{m}^{-3}\right)$

$\rho_{\text {ap }}$ : specific mass unit, $\left(\mathrm{kg} \mathrm{m}^{-3}\right)$

$\varepsilon:$ porosity, (\%)

The results were multiplied by ten and were expressed in grams. The volume $\left(\mathrm{V}_{\mathrm{g}}\right)$ of each seed was obtained following the drying process using a caliper according to the expression proposed by Mohsenin (1986):

$$
V g=\frac{\pi a b c}{6}
$$

which,

a: the major axis of seed, (mm)

b: mean axis of the seed, ( $\mathrm{mm})$

c: minor axis of the seed, (mm).

The acid index of the samples was determined according to the methodology described by the AOAC (2000), with three replications. The procedure was performed by placing $5 \mathrm{~g}$ sample into a $250 \mathrm{~mL}$ beaker, adding $150 \mathrm{~mL}$ ethanol and allowing to stand for approximately $30 \mathrm{~min}$, with agitation every $5 \mathrm{~min}$. The supernatant was then filtered through filter paper $(0.5 \mathrm{~mm})$ into an Erlenmeyer flask and another $100 \mathrm{~mL}$ ethanol was added, and the solution was left to stand for $15 \mathrm{~min}$ with agitation every $5 \mathrm{~min}$. The solution was then refiltered and four to five drops of phenolphthalein 
indicator solution (1\%) were added, and the solution was titrated with $\mathrm{NaOH} 0.1 \mathrm{~N}$ until a pink color was observed. Equation 9 was used to calculate of the index of acidity in $\mathrm{mg} \mathrm{NaOH} \mathrm{g}{ }^{-1}$.

$$
\text { Acidity index }=\frac{\mathrm{Vx} \mathrm{Nx} \text { F x } 40}{\mathrm{P}}
$$

which,

$\mathrm{V}$ : volume of $\mathrm{NaOH} 0.1 \mathrm{~N}$ titration spent, $(\mathrm{mL})$

$\mathrm{N}$ : normality

F: correction factor

P: weight of sample, $(\mathrm{g})$

\section{0: equivalent weight of $\mathrm{NaOH}$}

The amount of crude protein was determined for each sample via the Kjeldahl digestion method, described in AOAC (2000) in three replicates. This method was devised in 1983 and is based on three steps: digestion, distillation and titration. The process occurs by digesting the organic matter of the sample and the protein in ammonium sulphate $\left(\mathrm{NH}_{3} \mathrm{SO}_{4}\right)$ and digesting the mixture with sulphuric acid and heat. The organic material in the sample was digested with sulphuric acid and a catalyst, and the nitrogen was turned into ammonium salt. To determine the protein content, $1 \mathrm{~g}$ sample was weighed and was placed in a digestion tube, to which 1 pellet of copper $(\mathrm{Cu})$ catalyst and $15 \mathrm{~mL}$ sulphuric acid $\left(\mathrm{H}_{2} \mathrm{SO}_{4}\right)$ were added. The tubes were heated in the digester apparatus at a temperature of $420^{\circ} \mathrm{C}$ and were removed when a light-green color developed (after about $1 \mathrm{~h}$ ). After cooling, the sample was added to $70 \mathrm{~mL}$ distilled water and $30 \mathrm{~mL}$ boric acid in an Erlenmeyer flask. In the distillation step, ammonia was released from the ammonium salt by reaction with hydroxide. This occurred via the uptake of nitrogen, which was titrated and quantified. This procedure was carried out using a preheated tube distiller and a digester. With the aid of a lever contained in a retort, $\mathrm{NaOH}$ $(40 \%)$ was added to the tube and the mixture was distilled for about $4 \mathrm{~min}$. After distillation, titration was performed with $0.1 \mathrm{~N} \mathrm{H}_{2} \mathrm{SO}_{4}$. The titration volume was used in equation 10 to calculate the percentage crude protein in the sample.

$$
\mathrm{CP}(\%)=\frac{\mathrm{V}_{1} \times 0.4 \times \mathrm{F} \times 6.25}{\mathrm{P}}
$$

which,

CP: percentage of crude protein, (\%)

$\mathrm{V}_{1}$ : titrated volume, $(\mathrm{mL})$

0.14: gram equivalent nitrogen

F: correction factor solution of $\mathrm{H} \mathrm{SO}_{2} 0.1 \mathrm{~N}$

$\mathrm{P}$ : weight of sample, $(\mathrm{g})$

6.25: transformation of nitrogen in protein factor considering $16 \%$ of nitrogen.

Ash analysis was performed on a $2 \mathrm{~g}$ sample of ground jabotá seeds, which was placed in a tared porcelain crucible and heated at $100{ }^{\circ} \mathrm{C}$ in an oven and calcined at $600{ }^{\circ} \mathrm{C}$ in a muffle for $4 \mathrm{~h}$ at $600{ }^{\circ} \mathrm{C}$. The sample was then allowed to cool in a desiccator until it reached room temperature and was weighed (AOAC, 2000). After calcination, the determination of ash was obtained from the difference between the mass of the empty, previously calcined crucible and the mass of the crucible and calcite residue, considering the mass of the fresh sample.

The experimental design was completely randomized $(5 \times 3 \times 2)$, with five different types of packaging (plastic bags, paper bags, glass bottle, tetrapack, PET bottle), three forms of processing (with pulped, without pulped (scarified), without pulped (fermented)) and two different storage temperatures $\left(10\right.$ and $\left.23^{\circ} \mathrm{C}\right)$. An analysis of variance and comparison of means using the Tukey test at $5 \%$ probability were performed. 


\section{Results and Discussion}

The results of the physical and chemical analysis of jatobá-do-cerrado seeds at different storage temperatures $\left(10\right.$ and $\left.23{ }^{\circ} \mathrm{C}\right)$ were significant at 1 and $5 \%$ probability. However, significant differences $(P<0.05)$ were observed in the physical properties of jatobá-do-cerrado seeds subjected to different processing conditions, storage and packaging (Table1). The length, width and thickness of seeds ranged from 2.38 to $2.93 \mathrm{~cm}$, from 1.97 to $2.34 \mathrm{~cm}$ and from 1.39 to $1.74 \mathrm{~cm}$, respectively. These values were higher than found by Andrade et al. (2010) for Hymenaea courbaril L. species.

The diameter of the seed did not changes due to processing. According to Cruz et al. (2001), great variability exists in fruit size and the number of seeds and fruits in tropical tree species. Among the treatments, seeds with pulp were in terms of length, width and thickness than those in the other processes, although the temperature of storage and storage time had no significant effect. Similar results were observed for seed volume (Table 1).

The water content of the seeds increased from 9.71 to $13.43 \%$ (d.b.) at a storage temperature of 10 ${ }^{\circ} \mathrm{C}$ and 9.71 to $13.18 \%$ (w.b.) at $23{ }^{\circ} \mathrm{C}$, whereas the effects of processing were not significant. According to Carvalho (2005), the water content is extremely important for the physical and chemical properties of tree seeds, and is therefore very important at all stages of the seed technology processes, including handling, processing and storage. Increasing the water content of seeds caused changes in other physical properties, such as the mass and the apparent specific weight of the seeds (Table 1). The processing of the seeds and the removal of the pulp increased the bulk density, but no significant difference in this variable was observed at different storage temperatures. The seed weight increased with increasing storage time, especially of seeds with pulp, due to an increase in the percentage water content in the pulp of the seeds.
The circularity and sphericity of the seeds were important for processing by mechanical scarification. The sphericity ranged from 0.73 (seeds with pulp) to 0.84 (scarified seeds without pulp) and the circularity ranged from 0.66 (seeds with pulp) to 0.86 (scarified seeds without pulp). The storage conditions and time of storage had no significant effect on the roundness and sphericity of jatobá-do-cerrado seeds. The circular areas of the seeds were highest for seeds with pulp $\left(5.40 \mathrm{~cm}^{2}\right)$ and lowest for those after scarification $\left(3.77 \mathrm{~cm}^{2}\right)$. A similar pattern was observed for to the projected area of the seeds, however, the lowest values were obtained by pulp removal due to fermentation.

Significant changes $(P<0.05)$ were observed in the chemical quality of jatobá-do-cerrado seeds subjected to different processing conditions, storage and packaging (Table 2). There were no clear changes in the percentage of crude protein in jatobádo-cerrado seeds during storage after different processing conditions. However, among the types of processing, the percentage of crude protein was greater for shelled seeds (11.41\%) after fermentation after the third month of storage, which indicates a higher quality and less aggressive treatment of the seeds than the mechanical scarification process. A lower percentage of crude protein was found in the seeds with pulp $(9.32 \%)$ from the third month of storage onwards. A decreased percentage of ash was observed (Table 2) with an increasing storage time, regardless of the type of seed processing used. Among processing types, seeds whose pulp was removed by fermentation had the lowest percentage of ash $(1.34 \%)$ and the highest percentage was observed for the seed slurry $(2.53 \%)$. The acidity increased from the third month of storage, regardless of the type of processing and storage conditions (Table 2). The highest acidity value was observed for seeds with pulp $(9.73 \mathrm{~mL} 1 \mathrm{~N} \mathrm{NaOH})$ and the lowest for the seeds without pulp, after fermentation (4.71 mL $1 \mathrm{~N} \mathrm{NaOH})$. 
Table 1. Physical quality of jatobá seeds processed in different forms and stored in different conditions.

\begin{tabular}{|c|c|c|c|c|c|c|}
\hline \multirow{3}{*}{$\begin{array}{l}\text { Storage temperature } \\
\text { Storage time }\end{array}$} & \multicolumn{3}{|c|}{$10^{\circ} \mathrm{C}$} & \multicolumn{3}{|c|}{$23{ }^{\circ} \mathrm{C}$} \\
\hline & \multicolumn{3}{|c|}{ Time (months) } & \multicolumn{3}{|c|}{ Time (months) } \\
\hline & Zero & Three & Six & Zero & Three & Six \\
\hline \multicolumn{7}{|c|}{ Length $(\mathrm{cm})$} \\
\hline With pulp & $2.86 \mathrm{aB}$ & $2.87 \mathrm{aB}$ & $2.92 \mathrm{aB}$ & $2.86 \mathrm{aB}$ & $2.93 \mathrm{aB}$ & $2.86 \mathrm{aB}$ \\
\hline Without pulp (scarified) & $2.38 \mathrm{aA}$ & $2.41 \mathrm{aA}$ & $2.52 \mathrm{aA}$ & $2.38 \mathrm{aA}$ & $2.38 \mathrm{aA}$ & $2.53 \mathrm{aA}$ \\
\hline Without pulp (fermented) & $2.58 \mathrm{aA}$ & $2.56 \mathrm{aA}$ & $2.60 \mathrm{aA}$ & $2.58 \mathrm{aA}$ & $2.53 \mathrm{aA}$ & $2.57 \mathrm{aA}$ \\
\hline \multicolumn{7}{|c|}{ Width $(\mathrm{cm})$} \\
\hline With pulp & $2.32 \mathrm{aB}$ & $2.34 \mathrm{aB}$ & $2.28 \mathrm{aB}$ & $2.32 \mathrm{aB}$ & $2.29 \mathrm{aB}$ & $2.29 \mathrm{aB}$ \\
\hline Without pulp (scarified) & $1.99 \mathrm{aA}$ & $2.02 \mathrm{aA}$ & $2.05 \mathrm{aA}$ & $1.99 \mathrm{aA}$ & $2.00 \mathrm{aA}$ & $2.06 \mathrm{aA}$ \\
\hline Without pulp (fermented) & $1.97 \mathrm{aA}$ & $2.04 \mathrm{aA}$ & $2.06 \mathrm{aA}$ & $1.97 \mathrm{aA}$ & $2.08 \mathrm{aA}$ & $2.08 \mathrm{aA}$ \\
\hline \multicolumn{7}{|c|}{ Thickness $(\mathrm{cm})$} \\
\hline With pulp & $1.57 \mathrm{aA}$ & $1.67 \mathrm{aA}$ & $1.45 \mathrm{aA}$ & $1.57 \mathrm{aA}$ & $1.61 \mathrm{aA}$ & $1.53 \mathrm{aA}$ \\
\hline Without pulp (scarified) & $1.67 \mathrm{aA}$ & $1.74 \mathrm{aA}$ & $1.60 \mathrm{aA}$ & $1.67 \mathrm{aA}$ & $1.57 \mathrm{aA}$ & $1.47 \mathrm{aA}$ \\
\hline Without pulp (fermented) & $1.45 \mathrm{aA}$ & $1.49 \mathrm{aA}$ & $1.39 \mathrm{aA}$ & $1.45 \mathrm{aA}$ & $1.53 \mathrm{aA}$ & $1.52 \mathrm{aA}$ \\
\hline \multicolumn{7}{|c|}{ Volume $\left(\mathrm{cm}^{3}\right)$} \\
\hline With pulp & $5.57 \mathrm{aB}$ & $5.85 \mathrm{aB}$ & $5.05 \mathrm{aB}$ & $5.57 \mathrm{aB}$ & $5.65 \mathrm{aB}$ & $5.22 \mathrm{aB}$ \\
\hline Without pulp (scarified) & $4.19 \mathrm{aA}$ & $4.43 \mathrm{aA}$ & $4.34 \mathrm{aA}$ & $4.19 \mathrm{aA}$ & $3.95 \mathrm{aA}$ & $4.02 \mathrm{aA}$ \\
\hline Without pulp (fermented) & $3.88 \mathrm{aA}$ & $4.09 \mathrm{aA}$ & $3.92 \mathrm{aA}$ & $3.88 \mathrm{aA}$ & $4.26 \mathrm{aA}$ & $4.23 \mathrm{aA}$ \\
\hline \multicolumn{7}{|c|}{ Sphericity } \\
\hline With pulp & $0.76 \mathrm{aA}$ & $0.78 \mathrm{aA}$ & $0.73 \mathrm{aA}$ & $0.76 \mathrm{aA}$ & $0.75 \mathrm{aA}$ & $0.75 \mathrm{aA}$ \\
\hline Without pulp (scarified) & $0.83 \mathrm{aB}$ & $0.84 \mathrm{aB}$ & $0.80 \mathrm{aB}$ & $0.83 \mathrm{bB}$ & $0.82 \mathrm{bB}$ & $0.77 \mathrm{aA}$ \\
\hline Without pulp (fermented) & $0.75 \mathrm{aA}$ & $0.77 \mathrm{a} \mathrm{A}$ & $0.74 \mathrm{aA}$ & $0.75 \mathrm{aA}$ & $0.79 \mathrm{aB}$ & $0.78 \mathrm{aA}$ \\
\hline \multicolumn{7}{|c|}{ Circularity } \\
\hline With pulp & $0.66 \mathrm{aA}$ & $0.71 \mathrm{aA}$ & $0.62 \mathrm{aA}$ & $0.66 \mathrm{aA}$ & $0.69 \mathrm{aA}$ & $0.66 \mathrm{aA}$ \\
\hline Without pulp (scarified) & $0.83 \mathrm{aB}$ & $0.86 \mathrm{aB}$ & $0.77 \mathrm{aB}$ & $0.83 \mathrm{bB}$ & $0.77 \mathrm{bA}$ & $0.70 \mathrm{aA}$ \\
\hline Without pulp (fermented) & $0.72 \mathrm{aA}$ & $0.72 \mathrm{aA}$ & $0.66 \mathrm{aA}$ & $0.72 \mathrm{aA}$ & $0.72 \mathrm{aA}$ & $0.72 \mathrm{aA}$ \\
\hline \multicolumn{7}{|c|}{ Circularity area $\left(\mathrm{cm}^{2}\right)$} \\
\hline With pulp & $5.28 \mathrm{aB}$ & $5.38 \mathrm{aB}$ & $5.33 \mathrm{aB}$ & $5.28 \mathrm{aB}$ & $5.40 \mathrm{aB}$ & $5.24 \mathrm{aB}$ \\
\hline Without pulp (scarified) & $3.77 \mathrm{aA}$ & $3.88 \mathrm{aA}$ & $4.13 \mathrm{aA}$ & $3.77 \mathrm{aA}$ & $3.79 \mathrm{aA}$ & $4.17 \mathrm{aA}$ \\
\hline Without pulp (fermented) & $4.08 \mathrm{aA}$ & $4.18 \mathrm{aA}$ & $4.28 \mathrm{aA}$ & $4.08 \mathrm{aA}$ & $4.21 \mathrm{aA}$ & $4.26 \mathrm{aA}$ \\
\hline \multicolumn{7}{|c|}{ Average diameter $(\mathrm{cm})$} \\
\hline With pulp & $2.59 \mathrm{aB}$ & $2.60 \mathrm{aB}$ & $2.60 \mathrm{aB}$ & $2.59 \mathrm{aB}$ & $2.61 \mathrm{aB}$ & $2.57 \mathrm{aB}$ \\
\hline Without pulp (scarified) & $2.19 \mathrm{aA}$ & $2.21 \mathrm{aA}$ & $2.29 \mathrm{aA}$ & $2.19 \mathrm{aA}$ & $2.19 \mathrm{aA}$ & $2.30 \mathrm{aA}$ \\
\hline Without pulp (fermented) & $2.27 \mathrm{aA}$ & $2.30 \mathrm{aA}$ & $2.33 \mathrm{aA}$ & $2.27 \mathrm{aA}$ & $2.31 \mathrm{aA}$ & $2.32 \mathrm{aA}$ \\
\hline \multicolumn{7}{|c|}{ Projected area $\left(\mathrm{cm}^{2}\right)$} \\
\hline With pulp & $3.57 \mathrm{aB}$ & $3.73 \mathrm{aB}$ & $3.31 \mathrm{aA}$ & $3.57 \mathrm{aB}$ & $3.68 \mathrm{aB}$ & $3.41 \mathrm{aA}$ \\
\hline Without pulp (scarified) & $3.13 \mathrm{aA}$ & $3.28 \mathrm{aA}$ & $3.16 \mathrm{aA}$ & $3.13 \mathrm{aA}$ & $2.94 \mathrm{aA}$ & $2.92 \mathrm{aA}$ \\
\hline Without pulp (fermented) & $2.95 \mathrm{aA}$ & $3.00 \mathrm{aA}$ & $2.85 \mathrm{aA}$ & $2.95 \mathrm{aA}$ & $3.05 \mathrm{aA}$ & $3.06 \mathrm{aA}$ \\
\hline \multicolumn{7}{|c|}{ Water content (\% w.b.) } \\
\hline With pulp & $10.49 \mathrm{aA}$ & $13.43 \mathrm{bA}$ & $13.43 \mathrm{bA}$ & $10.49 \mathrm{aA}$ & $13.18 \mathrm{bA}$ & $13.18 \mathrm{bA}$ \\
\hline Without pulp (scarified) & $11.33 \mathrm{aB}$ & $12.77 \mathrm{bA}$ & $12.77 \mathrm{bA}$ & $11.33 \mathrm{aB}$ & $12.58 \mathrm{aA}$ & $12.58 \mathrm{aA}$ \\
\hline Without pulp (fermented) & $9.71 \mathrm{aA}$ & $13.25 \mathrm{aA}$ & $13.25 \mathrm{aA}$ & $9.71 \mathrm{aA}$ & $12.10 \mathrm{bA}$ & $12.10 \mathrm{bA}$ \\
\hline \multicolumn{7}{|c|}{ Bulk density apparent $\left(\mathrm{g} \mathrm{cm}^{-3}\right)$} \\
\hline With pulp & $1.03 \mathrm{aA}$ & $1.09 \mathrm{aA}$ & $1.21 \mathrm{bA}$ & $1.03 \mathrm{aA}$ & $1.13 \mathrm{aA}$ & $1.16 \mathrm{aA}$ \\
\hline Without pulp (scarified) & $1.13 \mathrm{aA}$ & $1.21 \mathrm{aB}$ & $1.27 \mathrm{aA}$ & $1.13 \mathrm{aA}$ & $1.28 \mathrm{bA}$ & $1.31 \mathrm{bA}$ \\
\hline Without pulp (fermented) & $1.31 \mathrm{aB}$ & $1.30 \mathrm{aB}$ & $1.31 \mathrm{aA}$ & $1.31 \mathrm{aB}$ & $1.26 \mathrm{aA}$ & $1.30 \mathrm{aA}$ \\
\hline \multicolumn{7}{|c|}{ Average weight (g) } \\
\hline With pulp & $5.51 \mathrm{aB}$ & $6.28 \mathrm{bB}$ & $6.01 \mathrm{bB}$ & $5.51 \mathrm{aB}$ & $6.33 \mathrm{bB}$ & $5.97 \mathrm{bB}$ \\
\hline Without pulp (scarified) & $4.71 \mathrm{aA}$ & $5.27 \mathrm{bA}$ & $5.50 \mathrm{bA}$ & $4.71 \mathrm{aA}$ & $4.98 \mathrm{aA}$ & $5.23 \mathrm{aA}$ \\
\hline Without pulp (fermented) & $5.06 \mathrm{aA}$ & $5.32 \mathrm{aA}$ & $5.13 \mathrm{aA}$ & $5.06 \mathrm{aA}$ & $5.32 \mathrm{aA}$ & $5.97 \mathrm{aA}$ \\
\hline
\end{tabular}

*Means followed by the capital letter in the column for each processing type and lower line for each storage time, do not differ at $5 \%$ probability. 
Table 2. Chemical quality of jatobá seeds processed in different forms and stored in different conditions.

\begin{tabular}{|c|c|c|c|c|c|c|}
\hline \multirow{3}{*}{$\begin{array}{l}\text { Storage temperature } \\
\text { Storage time }\end{array}$} & \multicolumn{3}{|c|}{$10^{\circ} \mathrm{C}$} & \multicolumn{3}{|c|}{$23{ }^{\circ} \mathrm{C}$} \\
\hline & \multicolumn{3}{|c|}{ Time (months) } & \multicolumn{3}{|c|}{ Time (months) } \\
\hline & Zero & Three & Six & Zero & Three & Six \\
\hline \multicolumn{7}{|c|}{ Crude protein $(\%)$} \\
\hline With pulp & $10.18 \mathrm{bA}$ & $9.71 \mathrm{aA}$ & $9.71 \mathrm{aA}$ & $10.18 \mathrm{bA}$ & $9.32 \mathrm{aA}$ & $9.32 \mathrm{aA}$ \\
\hline Without pulp (scarified) & $10.69 \mathrm{bA}$ & $10.11 \mathrm{aA}$ & $10.11 \mathrm{aA}$ & $10.69 \mathrm{aA}$ & $11.30 \mathrm{bB}$ & $11.30 \mathrm{bB}$ \\
\hline Without pulp (fermented) & $10.05 \mathrm{aA}$ & $11.41 \mathrm{bB}$ & $11.41 \mathrm{bB}$ & $10.05 \mathrm{aA}$ & $11.19 \mathrm{bB}$ & $11.19 \mathrm{bB}$ \\
\hline \multicolumn{7}{|c|}{ Ashes $(\%)$} \\
\hline With pulp & $2.53 \mathrm{bB}$ & $1.83 \mathrm{aC}$ & $1.83 \mathrm{aC}$ & $2.53 \mathrm{bB}$ & $1.91 \mathrm{aB}$ & $1.91 \mathrm{aB}$ \\
\hline Without pulp (scarified) & $2.39 \mathrm{bB}$ & $1.64 \mathrm{aB}$ & $1.64 \mathrm{aB}$ & $2.39 \mathrm{bB}$ & $1.69 \mathrm{aA}$ & $1.69 \mathrm{aA}$ \\
\hline Without pulp (fermented) & $2.17 \mathrm{bA}$ & $1.34 \mathrm{aA}$ & $1.34 \mathrm{aA}$ & $2.17 \mathrm{bA}$ & $1.56 \mathrm{aA}$ & $1.56 \mathrm{aA}$ \\
\hline \multicolumn{7}{|c|}{ Index acidity (ml NaOH $1 \mathrm{~N})$} \\
\hline With pulp & $6.73 \mathrm{aB}$ & $9.73 \mathrm{bB}$ & $9.73 \mathrm{bB}$ & $6.73 \mathrm{aB}$ & $9.15 \mathrm{bB}$ & $9.15 \mathrm{bB}$ \\
\hline Without pulp (scarified) & $4.63 \mathrm{aA}$ & $6.11 \mathrm{bA}$ & $6.11 \mathrm{bA}$ & $4.63 \mathrm{aA}$ & $6.40 \mathrm{bA}$ & $6.40 \mathrm{bA}$ \\
\hline Without pulp (fermented) & $4.28 \mathrm{aA}$ & $6.31 \mathrm{bA}$ & $6.31 \mathrm{bA}$ & $4.28 \mathrm{aA}$ & $6.44 \mathrm{bA}$ & $6.44 \mathrm{bA}$ \\
\hline
\end{tabular}

*Means followed by the capital letter in the column for each processing type and lower line for each storage time, do not differ at $5 \%$ probability.

Figure 1 shows the water content, weight and bulk density of the seeds for various packaging and storage times. Seed that were stored in glass bottles and tetrapacks had the highest water content, regardless of the storage temperature. The water content increased in seeds from the third month of storage in all types of packaging. The water content is fundamentally important, because it indicates the degree of seed maturation and influences physiological seed quality during storage (FONSECA et al., 2005; CARVALHO; NAKAGAWA, 2012). It also directly influences the metabolic processes in the seeds, and an increase in the water content leads to an increase in respiration rate and consequently, in metabolic activity (CORLETTI et al., 2007; SMIDERLE; SCHWENGBER, 2011).

Figure 1. Water contents, weight and bulk density of jatobá seeds stored in different packaging and storage conditions of temperature.

Storage temperature of $10^{\circ} \mathrm{C}$

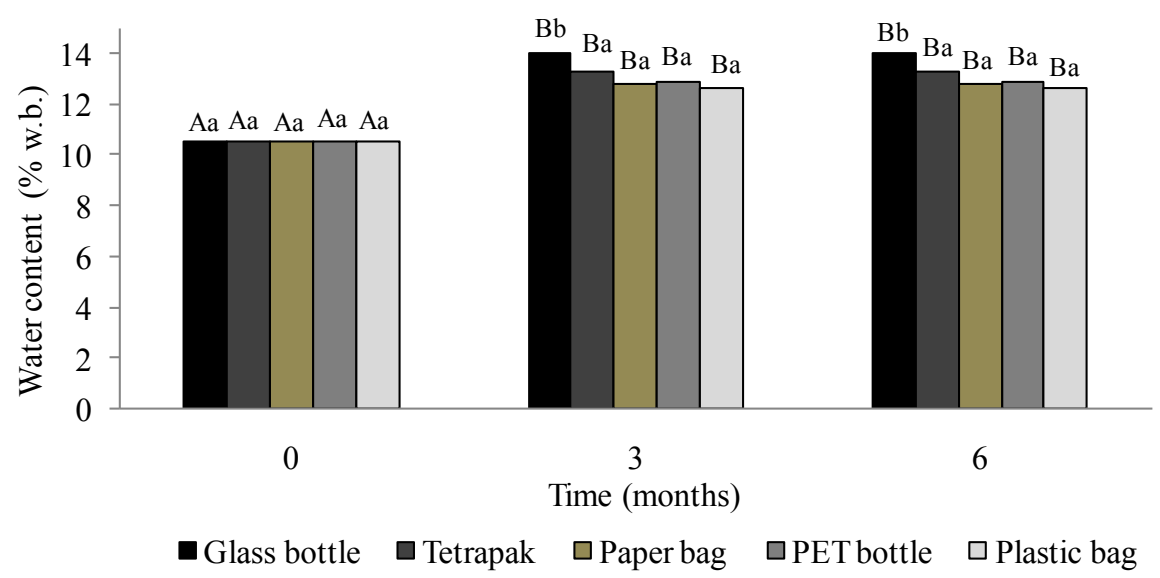


Storage temperature of $23{ }^{\circ} \mathrm{C}$

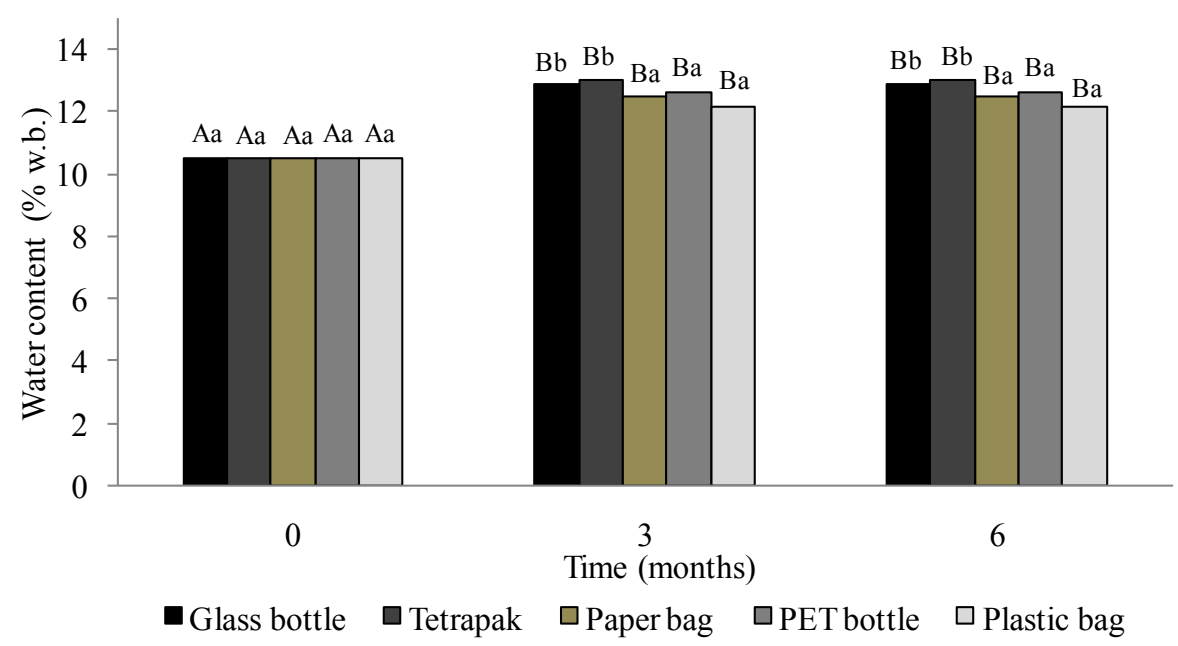

Storage temperature of $10{ }^{\circ} \mathrm{C}$

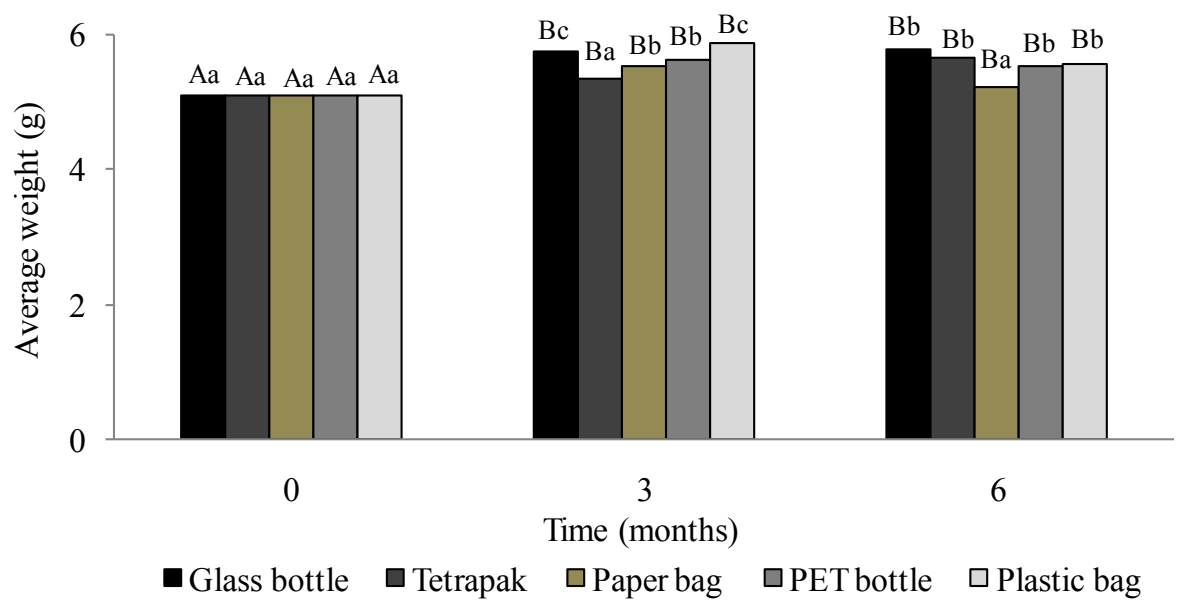

Storage temperature of $23{ }^{0} \mathrm{C}$

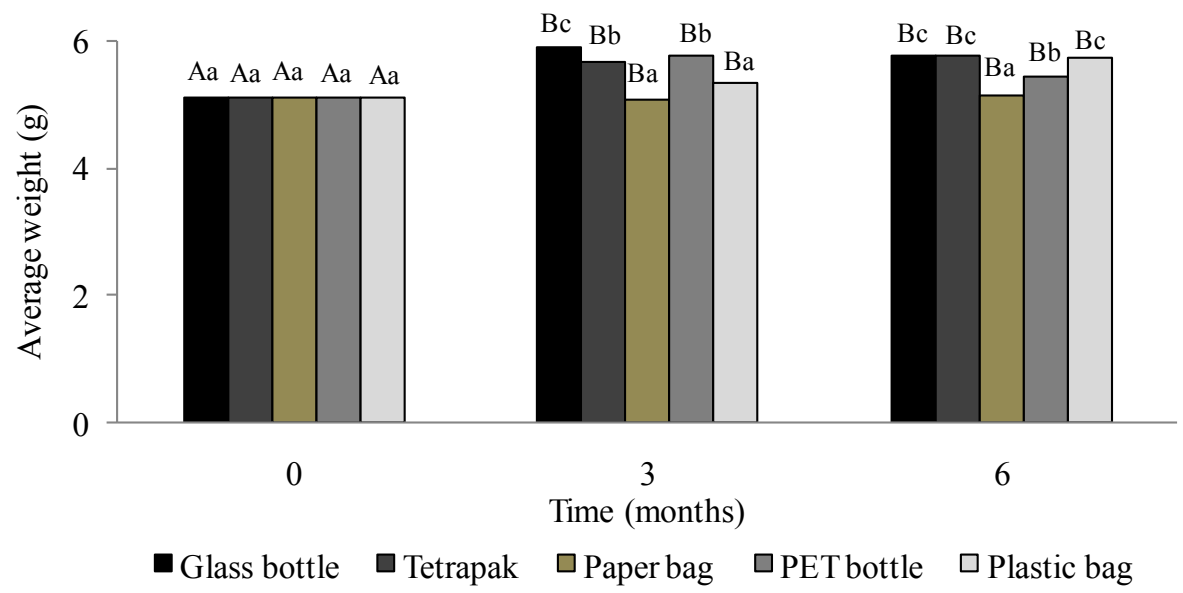


Storage temperature of $10{ }^{0} \mathrm{C}$

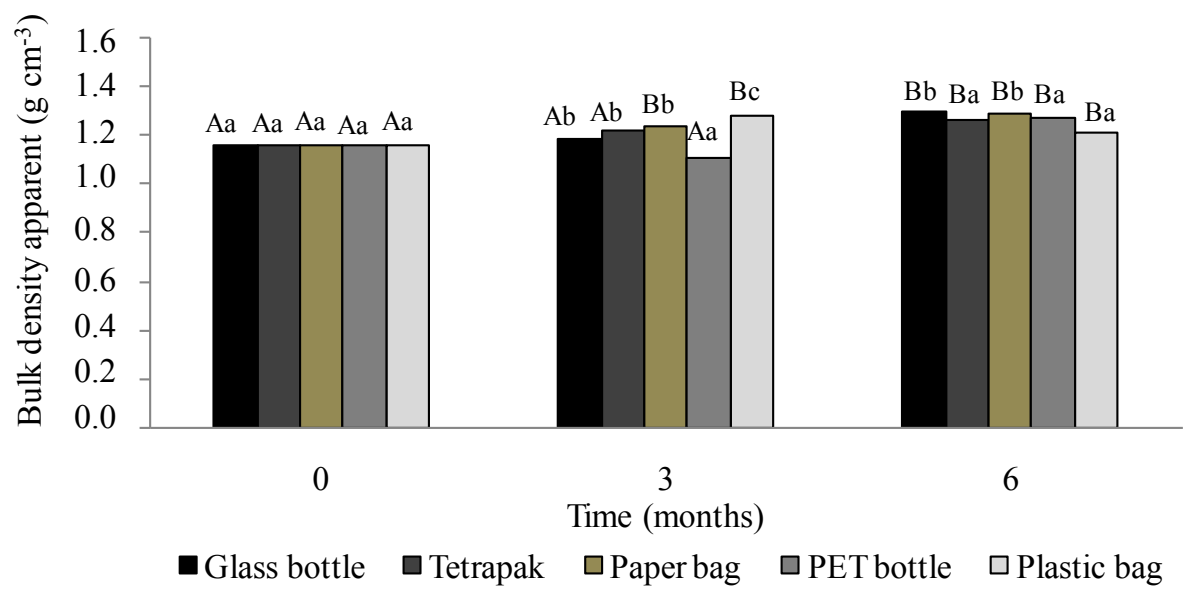

Storage temperature of $23{ }^{\circ} \mathrm{C}$

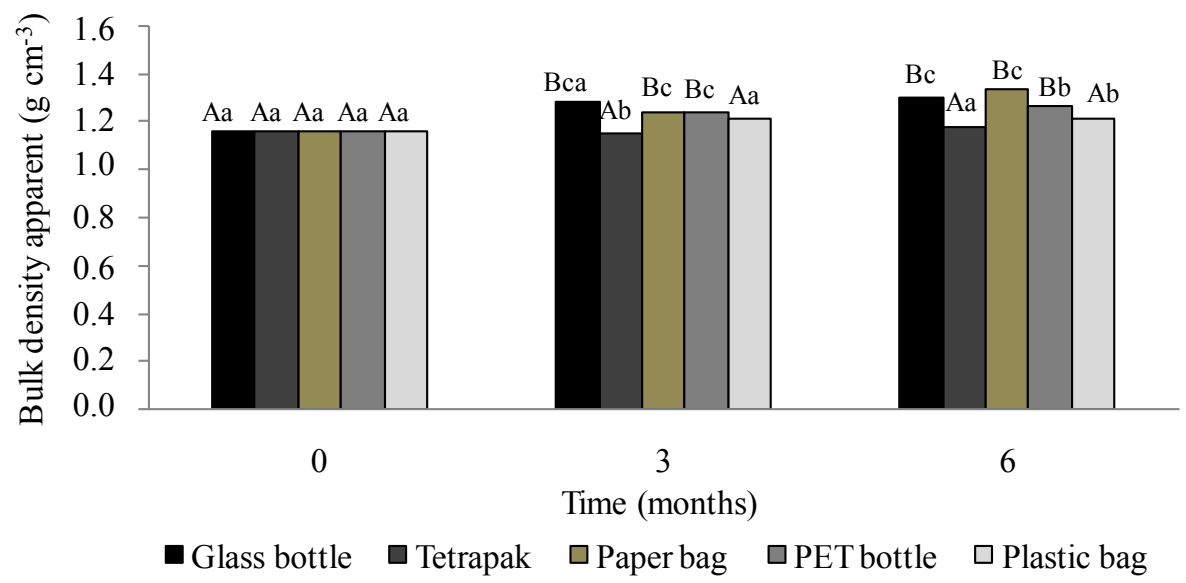

Means followed by the capital letter for the times of storage and lower letter for the types of packages, do not differ at $5 \%$ probability by test $t$.

During storage, the seeds gained weight and the water content increased. At both low and high storage temperatures $\left(10\right.$ or $\left.23{ }^{\circ} \mathrm{C}\right)$, the seeds lost more weight when they were stored in permeable packaging (paper bags and tetrapacks). The bulk density of the seeds (Figure 1) increased with increasing storage time, contrary to what rushes most agricultural products. Among the packaging types, glass bottles, PET bottles and paper bags resulted in the highest bulk density at both storage temperatures. Significant changes $(P<0.05)$ were observed in the length, thickness and width of jatobádo-cerrado seeds, depending on the packaging, but irrespective of the storage temperature (Figure 2). 
Figure 2. Size and volume jatobá seeds stored in different packaging and storage conditions of temperature.

Storage temperature of $10{ }^{\circ} \mathrm{C}$

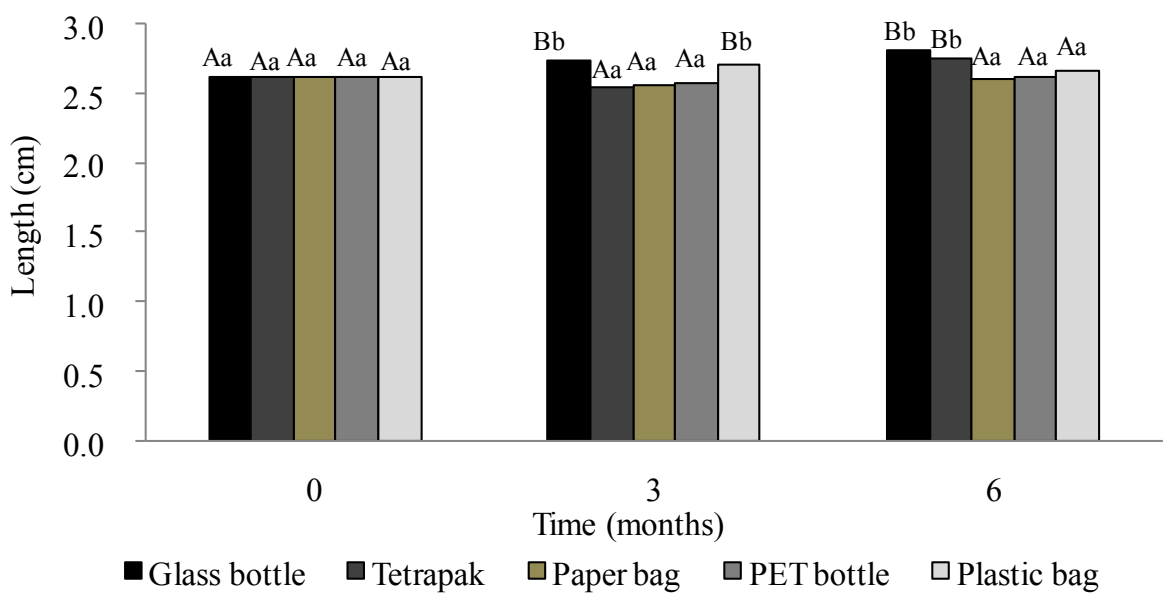

Storage temperature of $23{ }^{\circ} \mathrm{C}$
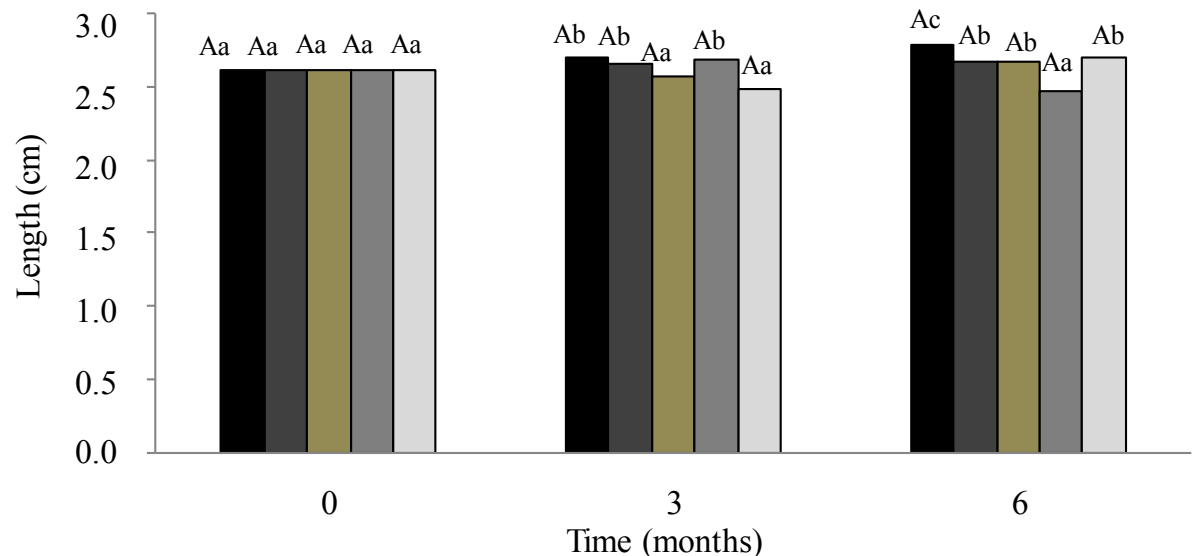

Time (months)

- Glass bottle $\square$ Tetrapak $\square$ Paperbag $\square$ PET bottle $\square$ Plastic bag

Storage temperature of $10{ }^{0} \mathrm{C}$

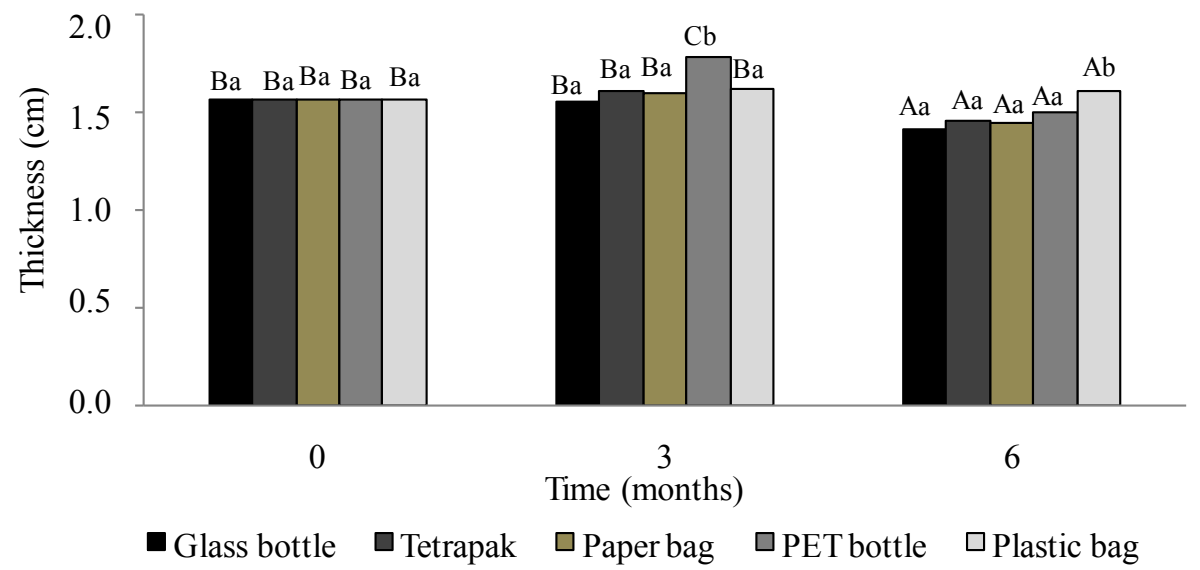


Storage temperature of $23{ }^{\circ} \mathrm{C}$

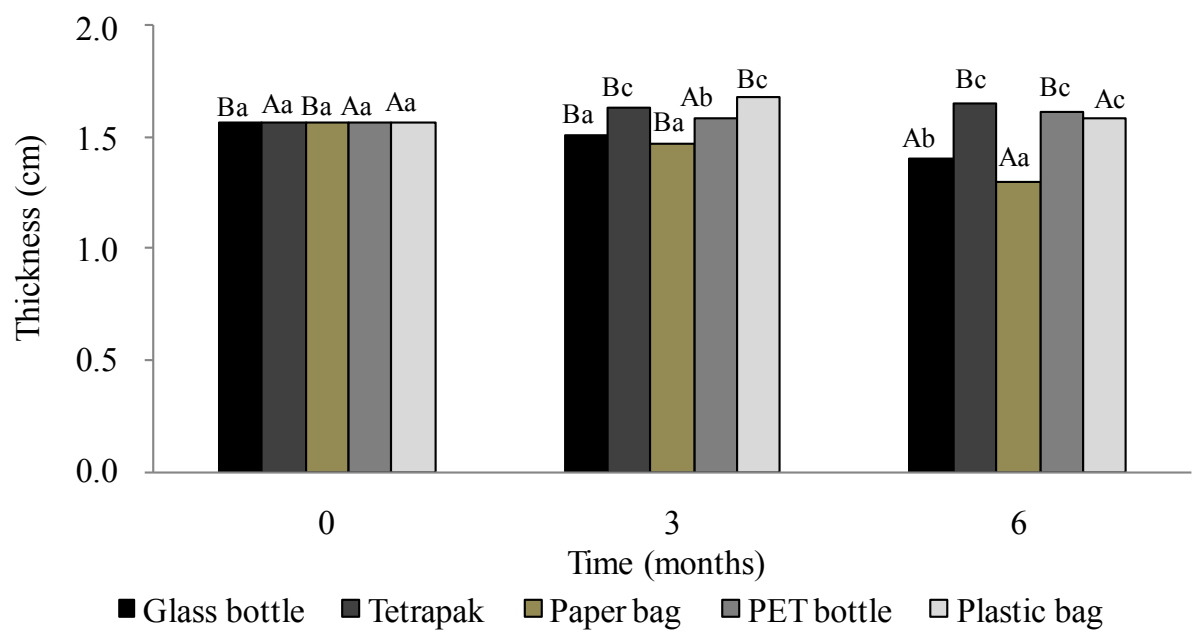

Storage temperature of $10{ }^{\circ} \mathrm{C}$

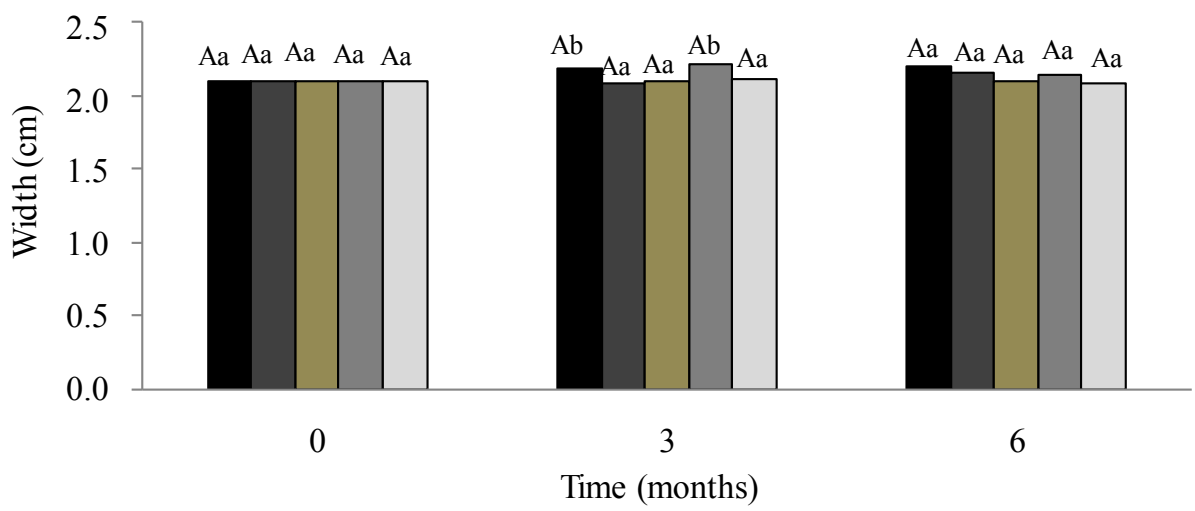

- Glass bottle $\square$ Tetrapak $\square$ Paperbag $\square$ PETbottle $\square$ Plastic bag

Storage temperature of $23{ }^{\circ} \mathrm{C}$

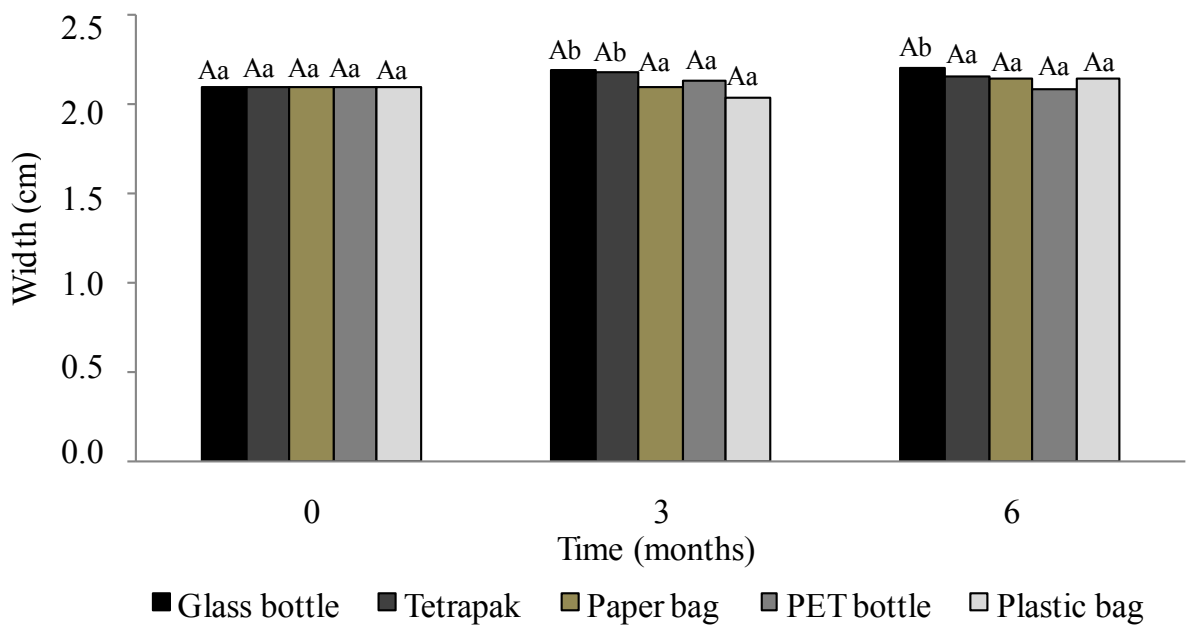


Storage temperature of $10^{\circ} \mathrm{C}$
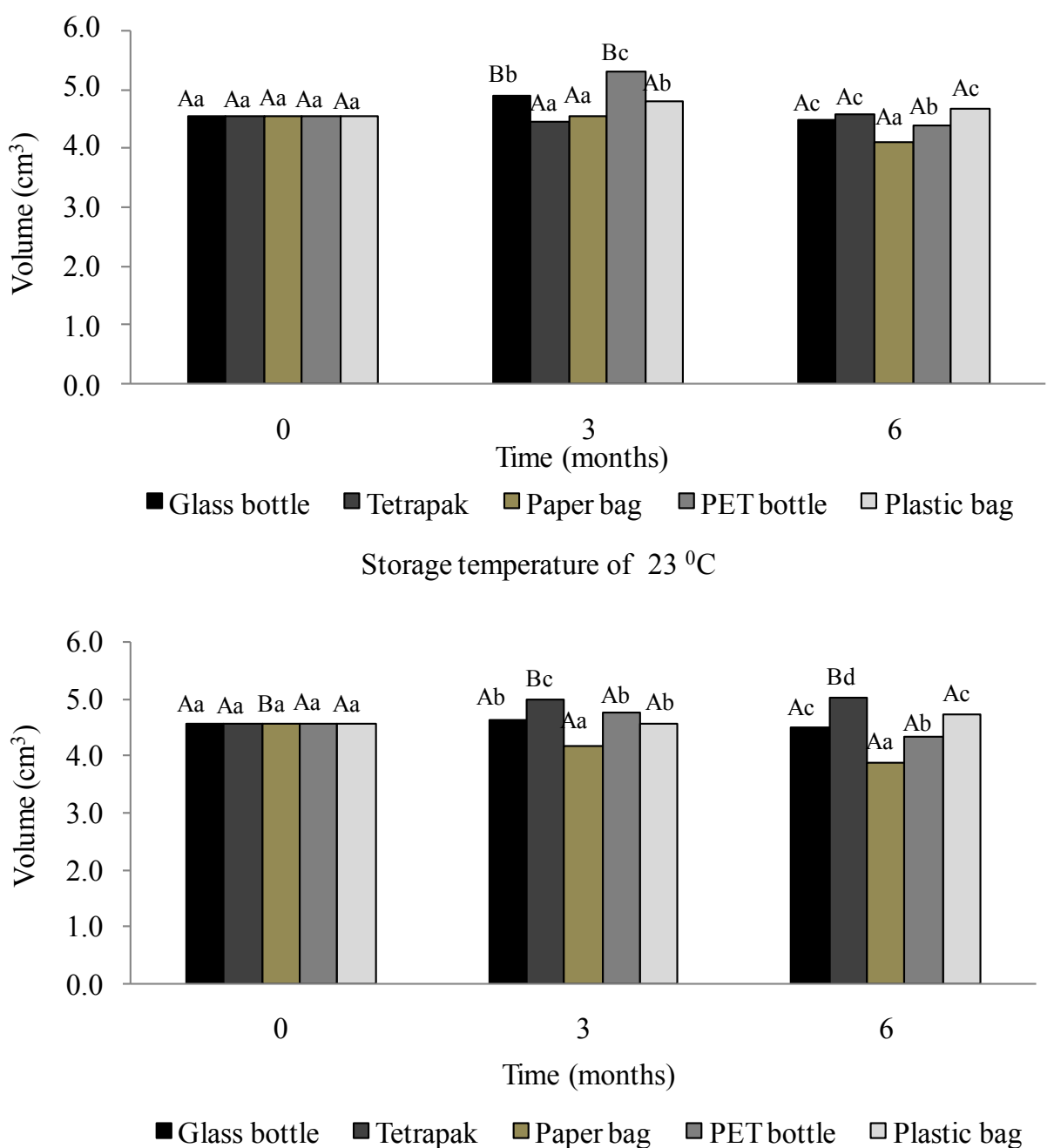

Means followed by the capital letter for the times of storage and lower letter for the types of packages, do not differ at $5 \%$ probability by test $\mathrm{t}$.

The length of the seeds increased with increasing storage time for storage in glass bottles, tetrapacks and plastic bags. The thickness of the stored seeds increased when the seeds were stored in PET bottles, after three months of storage at $10^{\circ} \mathrm{C}$, whereas after storage for six months, the thickness of the seeds decreased in most packaging treatments especially paper bags. Seed width varied, depending on the type of packaging used for storage. There was a greater increase in seed width when they were stored in glass jars and tetrapacks, and a reduction in seed width in plastic bags and paper packaging. Seed volume increased following storage in tetrapacks and PET bottles and decreased in seeds stored in paper bags. Significant differences $(P<0.05)$ were observed in the projected area, circular area, sphericity, roundness and diameter between different types of packaging, independent of the duration of storage and temperature (Figure 3).

Paper bag packaging had the greatest effect on the projected circular area, roundness, roundness and diameter of the seeds, whereas tetrapacks, glass bottles and PET bottles influenced the size of the seeds. The physical-chemical quality of jatobá-docerrado seeds was affected by time and different storage conditions and packaging (Figure 4). 
Figure 3. Dimensions of jatobá seeds stored in different packaging and storage conditions of temperature.

Storage temperature of $10{ }^{\circ} \mathrm{C}$

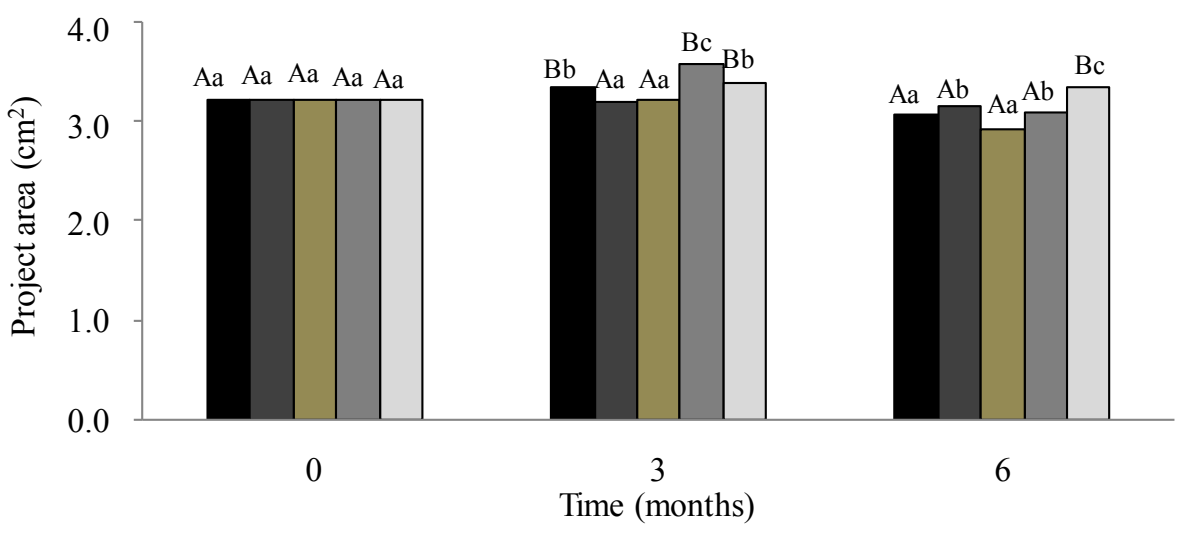

- Glass bottle $\quad$ Tetrapak $\square$ Paperbag $\quad \square$ PETbottle $\square$ Plastic bag

Storage temperature of $23{ }^{\circ} \mathrm{C}$

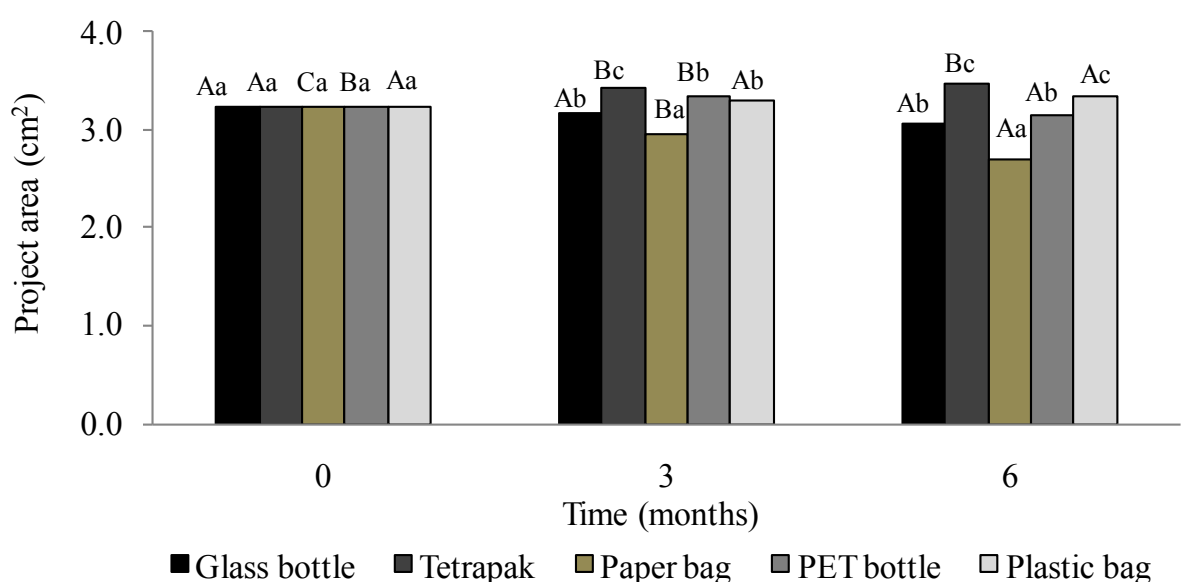

Storage temperature of $10{ }^{\circ} \mathrm{C}$

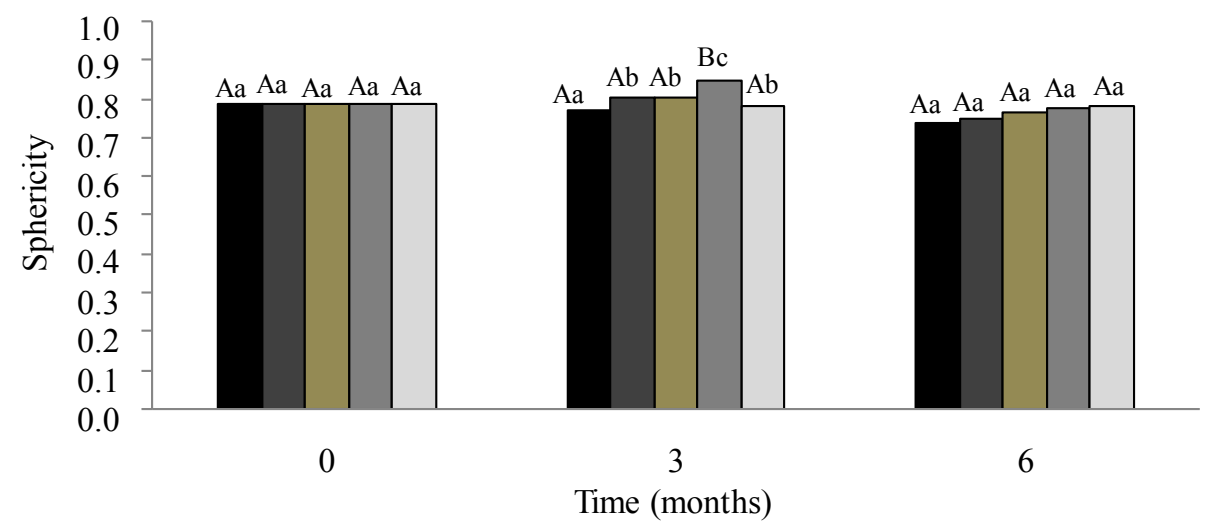

- Glass bottle $\square$ Tetrapak $\square$ Paperbag $\quad \square$ PETbottle $\square$ Plastic bag 
Storage temperature of $23{ }^{0} \mathrm{C}$

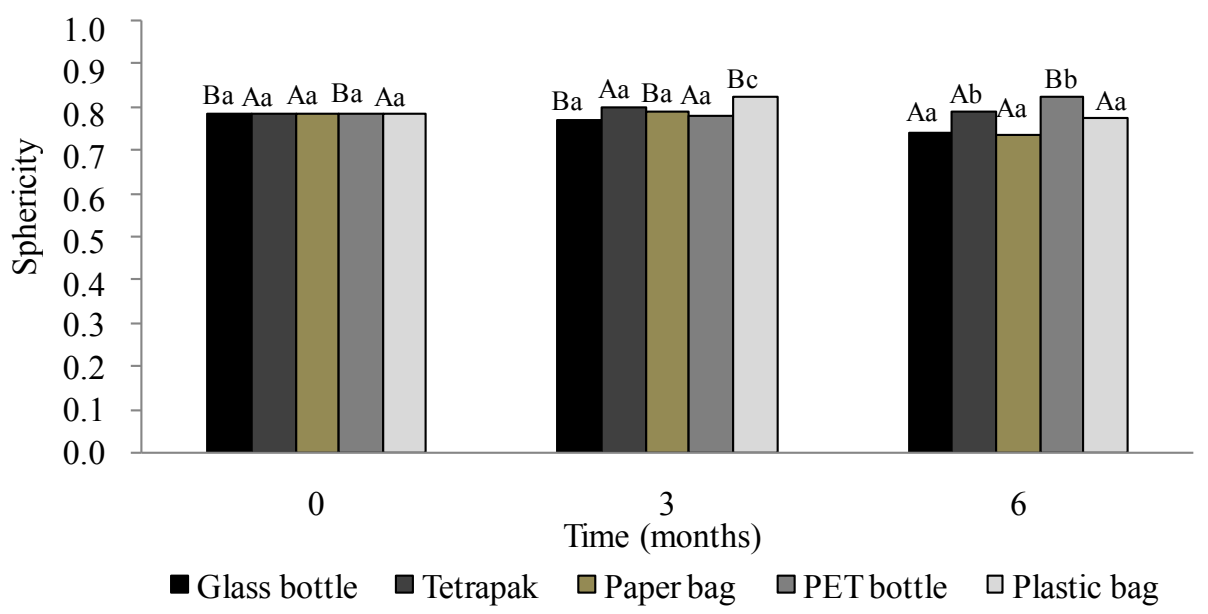

Storage temperature of $10^{\circ} \mathrm{C}$

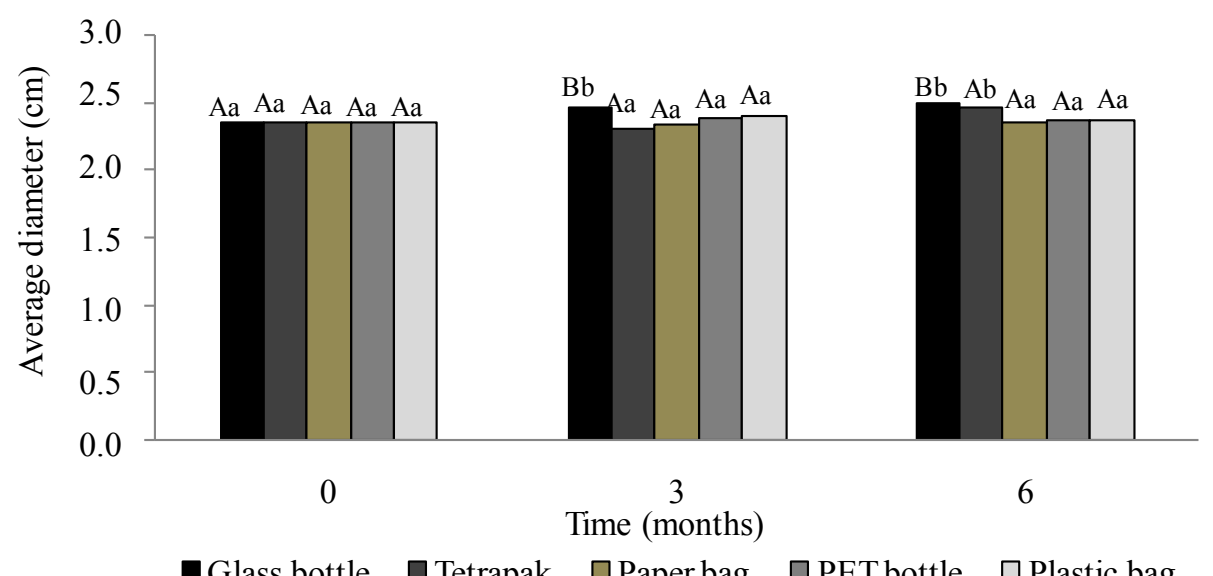

- Glass bottle $\square$ Tetrapak $\square$ Paperbag $\square$ PETbottle $\square$ Plastic bag

Storage temperature of $23{ }^{0} \mathrm{C}$

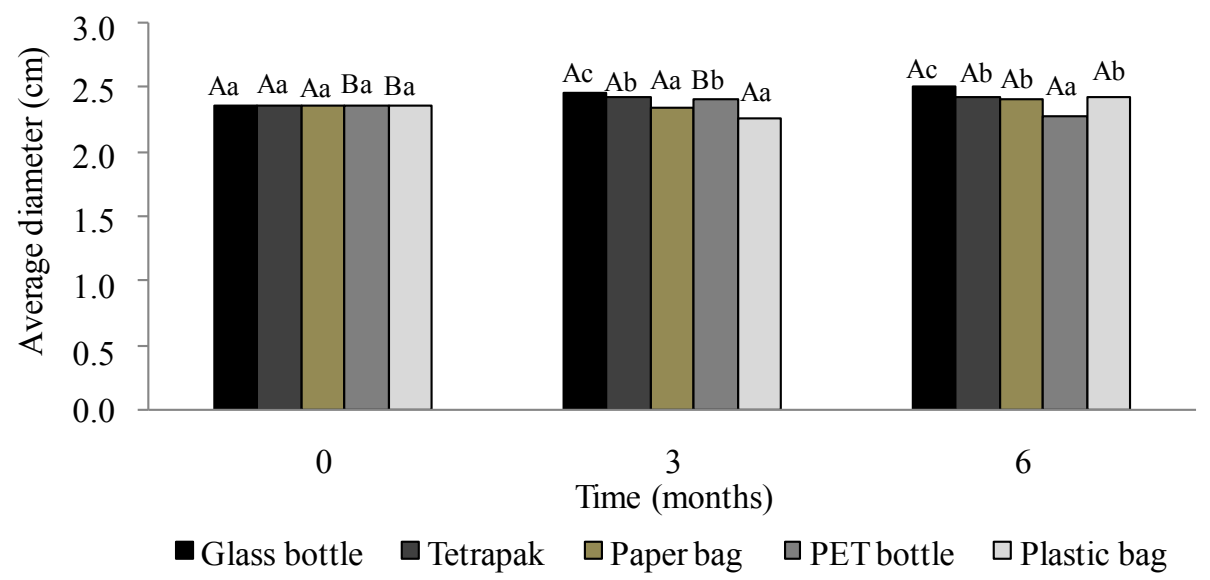


Storage temperature of $10^{\circ} \mathrm{C}$

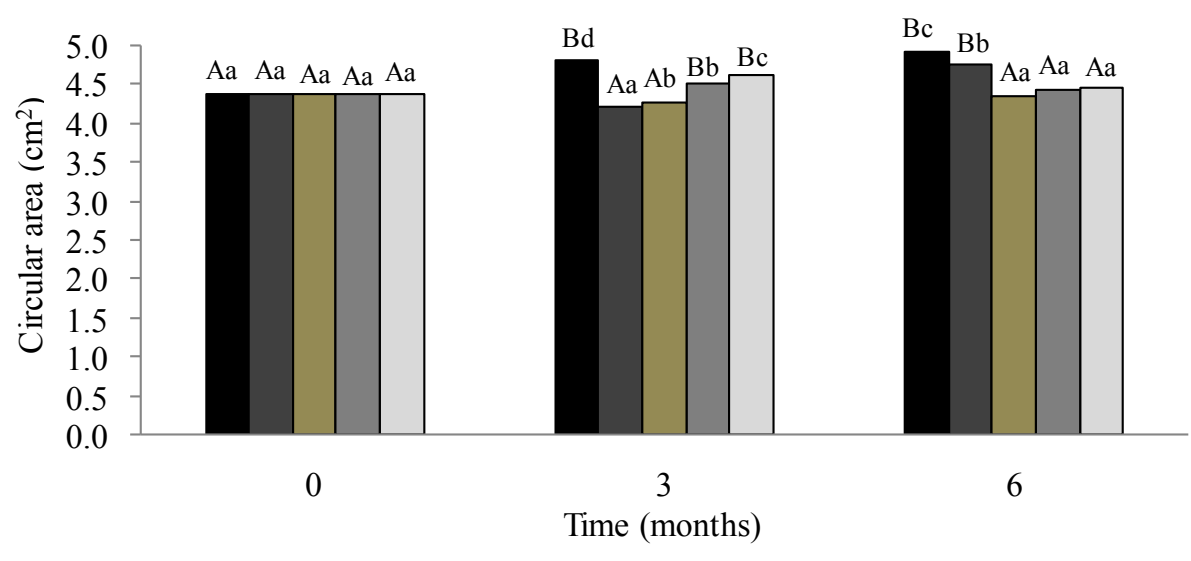

-Glass bottle $\quad$ Tetrapak $\square$ Paperbag $\square$ PETbottle $\square$ Plastic bag

Storage temperature of $23{ }^{0} \mathrm{C}$

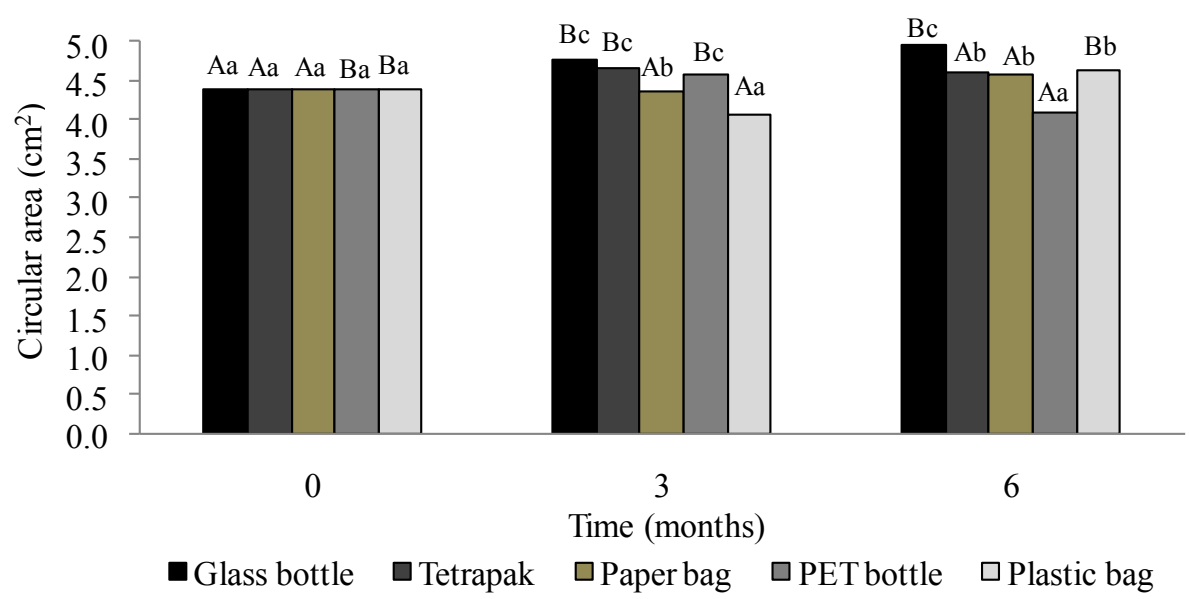

Means followed by the capital letter for the times of storage and lower letter for the types of packages, do not differ at $5 \%$ probability by test $t$.

Figure 4. Physical and chemical analysis jatobá seeds stored in different packaging and storage conditions of temperature.

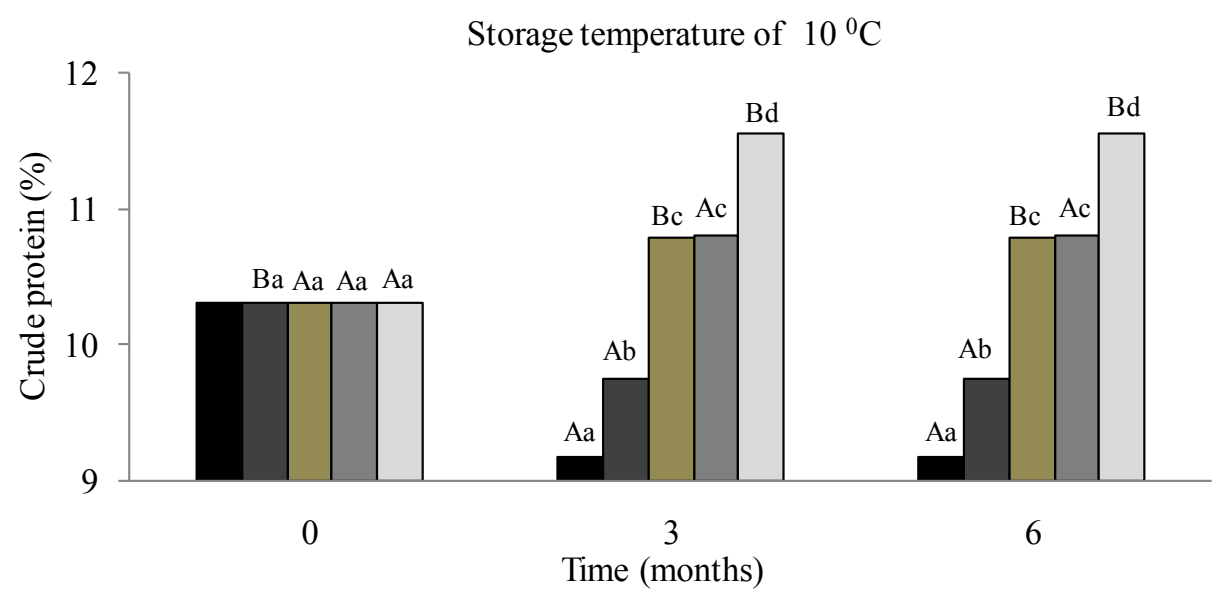

- Glass bottle $\quad$-Tetrapak $\square$ Paperbag $\quad \square$ PET bottle $\square$ Plastic bag 


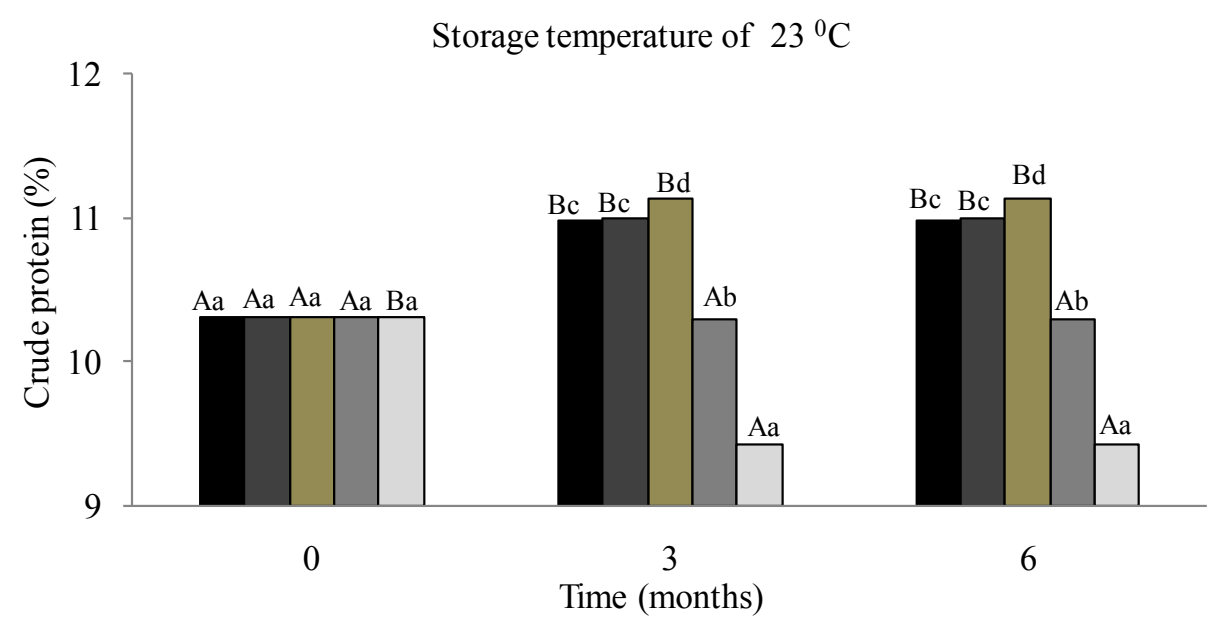

- Glass bottle $\square$ Tetrapak $\square$ Paperbag $\square$ PETbottle $\square$ Plastic bag

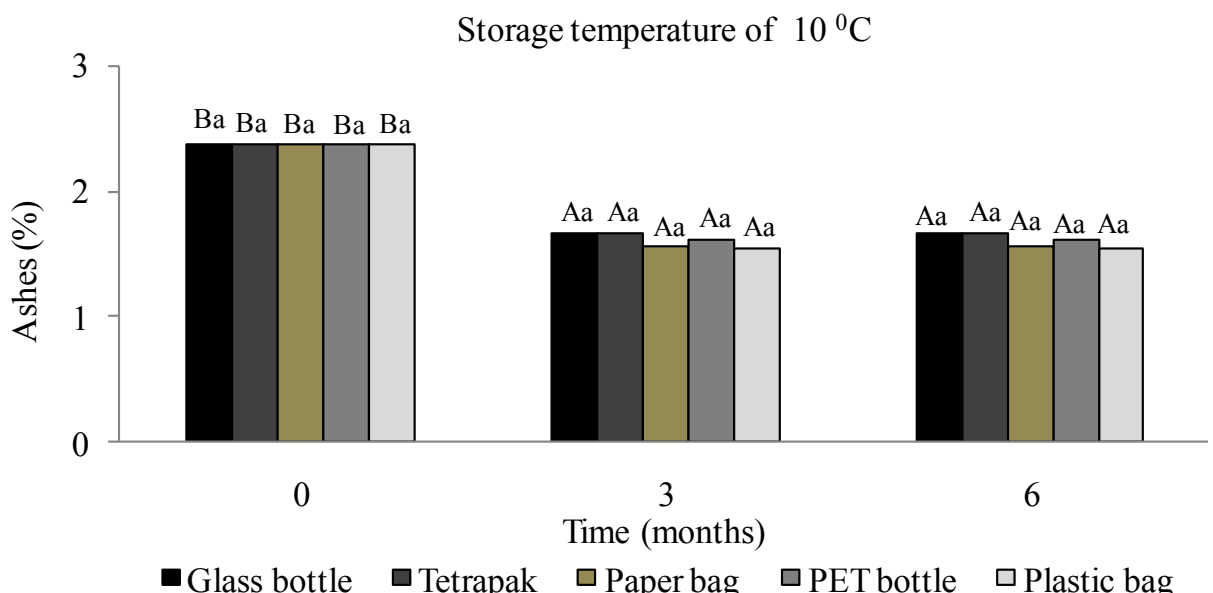

- Glass bottle $\square$ Tetrapak $\square$ Paperbag $\square$ PETbottle $\square$ Plastic bag

Storage temperature of $23{ }^{\circ} \mathrm{C}$

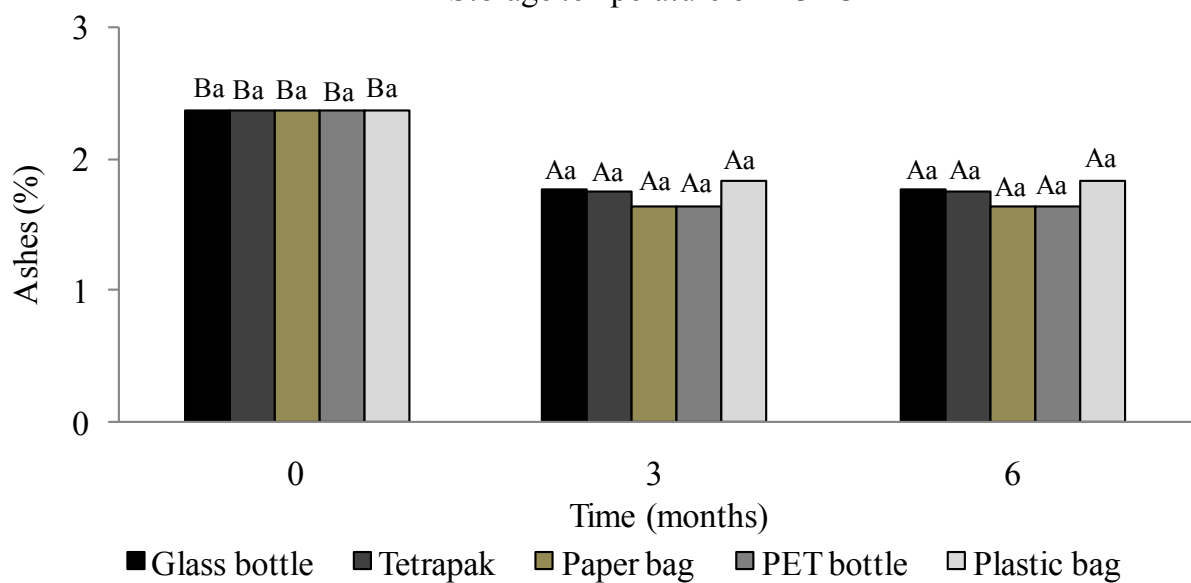


Storage temperature of $10^{\circ} \mathrm{C}$

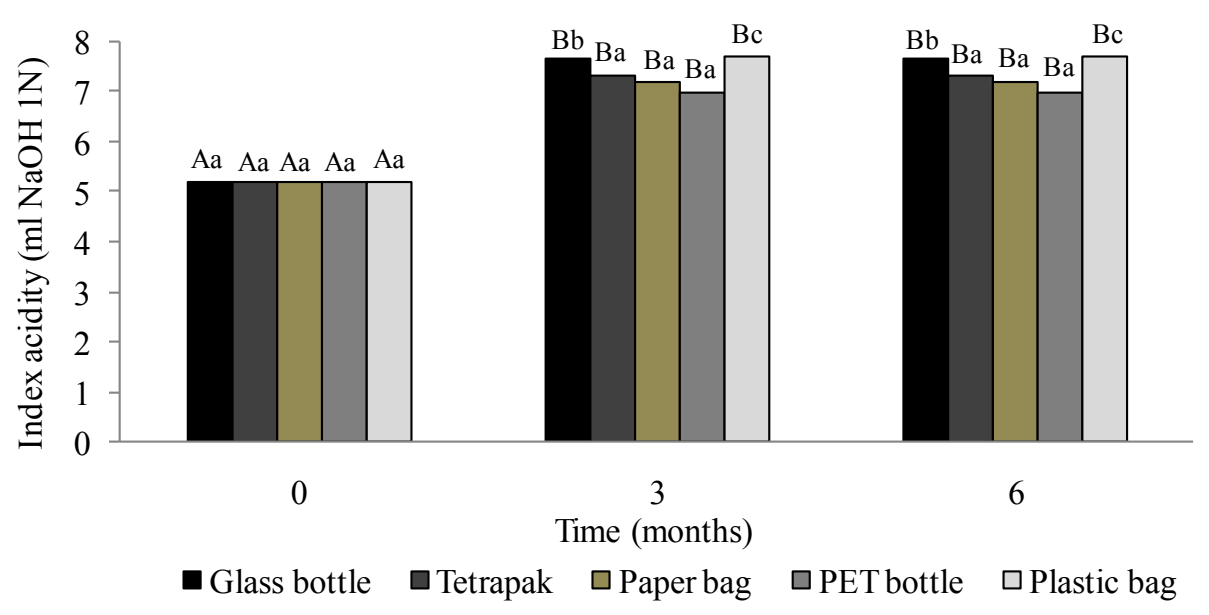

Storage temperature of $23{ }^{\circ} \mathrm{C}$

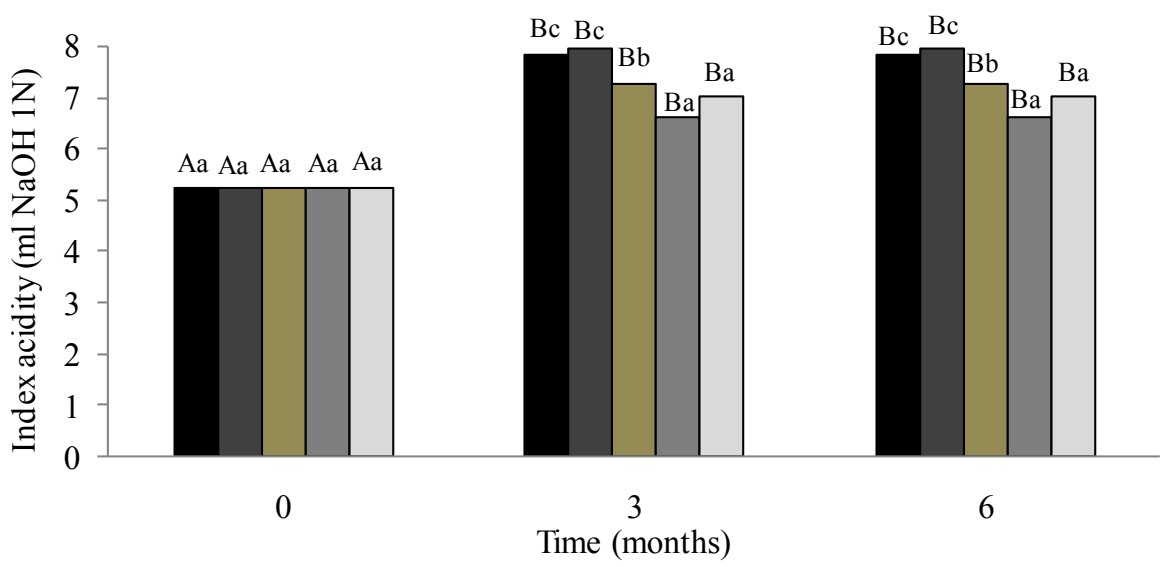

Means followed by the capital letter for the times of storage and lower letter for the types of packages, do not differ at $5 \%$ probability by test $t$.

The percentage of crude protein of seeds stored at $10{ }^{\circ} \mathrm{C}$ decreased after the third month of storage in tetrapacks and glass bottles, and it increased following storage in paper, plastic bags and PET bottles. At a storage temperature of $23{ }^{\circ} \mathrm{C}$, the opposite was observed: the highest percentage of crude protein was obtained in seeds stored in glass bottles, tetrapacks or paper, whereas seeds that were stored in PET bottles and plastic bags contained a lower percentage of crude protein. In contrast, the percentage of ash differed significantly between different durations of storage and types of packaging $(P<0.05)$.

Throughout the storage period, the percentage of ash decreased for all packaging types tested, and the greatest effects were observed for paper packaging, regardless of the storage conditions. Sousa et al. (2012) evaluated jatobá-do-cerrado seeds and found the following results for moisture (10.69\%); ash (2.34\%); crude protein $(8.63 \%)$ and lipids (25.50\%). Matuda and Maria Neto (2005) also studied the chemical composition of jatobá-docerrado seeds and obtained the following results for moisture, ash, protein and lipids $(10.18 \%, 1.80 \%$, $9.05 \%$ and $5.3 \%$ ). The acidity values of the seeds increased during storage for all types of packaging tested, especially in glass containers and tetrapacks. Seed acidity values for Jatobá-do-cerrado are scarce in the literature, because the vast majority of studies only mention the acidity of the oil from seeds, or that in the pulp or processed flour. 


\section{Conclusion}

The best processing treatment for jatobá-docerrado seeds was the fermentation method, and the best storage condition was in impermeable containers (glass and PET bottles).

\section{Acknowledgement}

The authors thank the UFMS -Federal University of Mato Grosso do Sul and the FUNDECT - MS Foundation for Development Support of Education, Science and Technology of the State of Mato Grosso do Sul for financial support for the development of research.

\section{References}

ALVES, E. U.; BRUNO, R. L. A.; ALVES, A. U.; ALVES, A. U.; CARDOSO, E. A.; GALINDO, E. A.; BRAGA JUNIOR, J. M. Germinação e biometria de frutos e sementes de Bauhinia divaricata L. Sitientibus Série Ciências Biológicas, Feira de Santana, v. 7, n. 3, p. 193-198, 2007.

ANDRADE, L. A.; BRUNO, R. L. A.; OLIVEIRA, L. S. B.; SILVA, H. T. F. Aspectos biométricos de frutos e sementes, grau de umidade e superação de dormência de jatobá. Acta Scientiarum. Agronomy, Maringá, v. 32, n. 2, p. 293-299, 2010.

ASSOCIATION OF OFFICIAL ANALYTICAL CHEMISTS - AOAC. Official methods of analysis of the Association of Official Analytical Chemists. 17 ${ }^{\text {th }}$ ed. Gaithersburg, Maryland: AOAC, 2000. v. 2, n. 11, 4 p.

BRAVO, L.; GRADOS, N.; SAURA-CALIXTO, F. Composition and potential uses of mesquite pods: comparison with carob pods. Journal Science Food Agricultural, New York, v. 65, n. 3, p. 303-306, 1994.

CARVALHO, N. M. A secagem de sementes. São Paulo: Funep, 2005. 184p.

CARVALHO, N. M.; NAKAGAWA, J. Sementes: ciência, tecnologia e produção. 5. ed. Jaboticabal: Funep, 2012. $590 \mathrm{p}$.

CORLETTI, F. M. F.; BARROS, A. C. S. A.; VILLELA, F. A. Qualidade fisiológica de sementes de urucum armazenadas em diferentes ambientes e embalagens. Revista Brasileira de Sementes, Londrina, v. 29, n. 2, p. 148-158, 2007.
CRUZ, E. D.; MARTINS, F. O.; CARVALHO, J. E. U. Biometria de frutos e sementes e germinação de jatobá curuba (Hymenaea intermedia Ducke, leguminosaeCaesalpinioideae). Revista Brasileira de Botânica, São Paulo, v. 24, n. 2, p. 161-165, 2001.

FONSECA, F. L.; MANEGARIO, C.; MORI, E. S.; NAKAGAWA, J. Maturidade fisiológica de sementes de Ipê Amarelo, Tabebuia chrysotricha (Mart. Ex DC.) Standl. Scientia Forestalis, Piracicaba, v. 69, n. 69, p. 136-141, 2005.

GOMES JUNIOR, F. G. Aplicação da análise de imagens para avaliação da morfologia interna de sementes. Informativo ABRATES, Londrina, v. 20, n. 3, p. 33-51, 2010.

MATUDA, T. G.; MARIA NETTO, F. Caracterização química parcial da semente de jatobá-do-cerrado (Hymenaea stigonocarpa Mart.). Ciência e Tecnololgia de Alimentos, Campinas, v. 25, n. 2, p. 353-357, 2005.

MOHSENIN, N. N. Physical properties of plant and animal materials. New York: Gordon \& Breach, 1986. $841 \mathrm{p}$.

OLIVEIRA, A. K. M.; RIBEIRO, J. W. F.; PEREIRA, K. C. L.; SILVA, C. A. A. Germinação de sementes de Aspidosperma tomentosum Mart. (Apocynaceae) em diferentes temperaturas. Revista Brasileira de Biociências, Porto Alegre, v. 9, n. 3, p. 392-397, 2011.

Temperaturas para germinação de sementes de Tabebuia ochracea (Cham.) Standl. Comunicata Scientiae, Teresina, v. 3, n. 2, p. 98-103, 2012.

SMIDERLE, O. J.; SCHWENGBER, L. A. M. Superação de dormência em sementes de paricana (Bowdichia virgilioides Kunth.). Revista Brasileira de Sementes, Londrina, v. 33, n. 3, p. 407-414, 2011.

SILVA, M. R.; SILVA, M. S.; MARTINS, K. A.; BORGES, S. Utilização tecnológica dos frutos de jatobá-do-cerrado e de jatobá-da-mata na elaboração de biscoitos fontes de fibra alimentar e isentos de açúcares. Ciência e Tecnologia de Alimentos, Campinas, v. 21, n. 2, p. 176-182, 2001.

SOUSA, E. P.; SILVA, L. M. M.; SOUSA, F. C.; FERRAZ, R. R.; FAÇANHA, L. M. Physic-chemical characterization of mealy fruits and seeds of the locust tree. Revista Verde de Agroecologia e Desenvolvimento Sustentável, Pombal, v. 1, n. 2, p. 117-121, 2012. 
